\title{
鉄筋腐食により定着不良を生じた RCはり部材の耐荷性状評価
}

\author{
村上 祐貴 1 - 董 衛 $^{2} \cdot$ 大下 英吉 $3 \cdot$ 鈴木 修一 4 - 堤 知明 5 \\ 1正会員 長岡工業高等専門学校助教 環境都市工学科（干940-8532 新潟県長岡市西片貝町888番地） \\ E-mail: y-murakami@nagaoka-ct.ac.jp \\ 2正会員 中央大学大学院 理工学研究科 土木工学専攻（广112-8551 東京都文京区春日1-13-27) \\ E-mail: dongwei@civil.chuo-u.ac.jp \\ 3正会員 中央大学教授 理工学部 都市環境学科（干112-8551 東京都文京区春日1-13-27） \\ E-mail: oshita@civil.chuo-u.ac.jp \\ 4正会員 東電設計株式会社 土木本部（干112-0015 東京都台東区東上野3-3-3） \\ E-mail: dshu@tepsco.co.jp \\ 5正会員 東京電力株式会社 技術開発研究所（干230-8510 横浜市鶴見区江ヶ崎町4-1） \\ E-mail: Tsutsumi.Tomoaki@tepco.co.jp
}

\begin{abstract}
本研究では，鉄筋腐食により主鉄筋の定着不良を生じたRCはり部材の曲げ耐荷性状およびせん断耐荷 性状評価を目的として, 断面諸元, 鉄筋腐食レベルなどが異なるRCはり部材に対して曲げ載荷実験を実 施した。主鉄筋軸方向ひずみ分布性状に基づき，設計時からの耐荷機構の遷移や而荷性状について検討を 行った結果，主鉄筋の付着劣化に伴い，主鉄筋を介して，荷重が支点外側の領域まで伝達した場合，はり の而荷機構が梁機構からアーチ機構に変化した. その際の耐荷性状は定着性能およびa/dに大きく影響す ることが明らかとなった。 また, 定着不良を考慮した腐食RCはり部材の残存耐力算定式を提案し, 断面 諸元，荷重条件によらず既往の実験結果を概ね評価可能であることを示した.
\end{abstract}

Key Words : corrosion of reinforcement, defective anchorages, flexural strength, shear strength, bond stress, anchorage performance

\section{1. はじめに}

現在，構造物を新設する時代から，既設構造物を適切 に維持管理し長期的に使用寸る時代一と移り変わってい る. 例えば米国においては, 設計供用期間中, 要求され る構造性能を発揮させるため, 膨大な諸元データ, 点検 データ, 補修履歴データ等をデータベース化し, 橋梁群 および個別の橋梁に対して補修計画の策定を支援するシ ステム（PONTIS）が確立されている.

一方，わが国においても，而久設計という概念がコン クリート標淮示方書に規定され, 維持管理体系の強化が 着々と進んではいるが，PONTISのようなデータベース は存在せず, 現状においては理論的に裏付けされた維持 管理活動を行う必要がある. また，維持管理の体系化が 比較的進んでいる米国においても想定外，或いは想定以 上に構造物の劣化損傷が進行し甚大な事故に発展する事 例も報告されている，例えば，2005年12月にアメリカ，
ペンシルバニア州で発生したコンクリート道路橋の崩落 事故は同年8月に性能検査が実施されたが，その直後の 崩落事故であった．また，カナダ，ケベック州において も2005年9月に検查された道路橋がその4ケ月後に崩落す る大事故が発生した.

このような背景から，近年では各種劣化損傷を生じた $\mathrm{RC}$ 構造物の現有性能評価について多方面で研究が実施 されている. 特に, 四方を海で囲まれたわが国では, 塩 害による鉄筋腐食劣化が大きな問題となっており，体系 的な取り組みがなされている1).

鉄筋腐食を生じたRC構造物の構造性能評価に関する 既往の研究を大別すると, 曲げ耐荷性能について検討す る研究とせん断而荷性能について検討寸る研究に区分さ れる. 曲げ而荷性能に関しては, 鉄筋腐食に伴う主鉄筋 の断面減少率 (腐食率) が曲げ耐力に支配的な要因であ るとされ，主鉄筋の腐食率と残存曲げ耐力を関連付けて 整理する場合が多い2) 、、、ずれの研究においても主鉄 
筋の腐食率に応じて, 曲げ而力が線形的に低下寸る見解 に相違はないが，その低下割合は研究毎に異なっており， 統一的に評価し得る予測式の提案には至っていない.

せん断而荷性能に着目した研究では, 鉄筋腐食に起因 して主鉄筋の付着劣化が生じることによりアーチ而荷機 構が形成され，非腐食時よりも耐力が増加するといった 報告が多( ${ }^{8) ~ 12) . ~}$

一方，既往の研究では，主鉄筋の端部定着が十分に確 保された状態において検討がなされているが，近年，ア ルカリ骨材反応により主鉄筋端部曲げ加工部の破断事例 が報告されており，主鉄筋の定着が十分ではない構造物 の存在が懸念される ${ }^{13)}$. また, このような構造物に対し て, 定着が十分に確保された状態で得られた既往の知見 を適用できるかどうかについては検討されていない.

このような背景から，著者らは主鉄筋端部の定着不良 を生じた腐食RCはりの残存曲げ耐荷性能について検討 を行ってきたの゙、その結果，主鉄筋の付着劣化により支 点外側の領域まで荷重伝達がなされ，主鉄筋定着領域に 損傷を受けている場合には，主鉄筋の断面減少以上に耐 力低下の生じる場合があることを明らかとした．しかし
ながら，定着不良時における而荷性能の大幅な低下やそ の影響因子を特定したものの，それら因子が耐荷性状に 及ぼす影響の定量化に際しては十分ではなく，部材の形 状寸法も一種類のみに対する検討であった.

そこで，本研究では鉄筋腐食を生じたRCはり部材の 残存而荷性状について主鉄筋の定着性能という観点から 定量的な評価を行った. 具体的には，主鉄筋の平均的な 腐食率に加えて, 形状寸法の異なるRCはり部材に対し て鉄筋腐食の不均一性や腐食ひび割れ性状および主鉄筋 とコンクリートの付着性能の低下といった鉄筋腐食に起 因した各種腐食劣化現象が，RCはり部材の残存而荷性 状に及ぼす影響について実験的, 解析的検討を行うとと もに，鉄筋腐食を生じたRCはり部材の耐荷機構の遷移 ならびに耐荷力評価式を提案した。

\section{2. 実験方法}

実験パラメータおよび実験結果の一覧を表ー1に示寸. 各試験体の断面諸元などの詳細は後述する. 試験体は大

表-1 実験パラメータおよび実験結果

\begin{tabular}{|c|c|c|c|c|c|c|c|c|c|c|c|c|}
\hline \multirow{25}{*}{ せん断破壊型 } & 断面 & シリーズ & 試験体名 & $\begin{array}{c}\text { せん断スパン比 } \\
(\mathrm{a} / \mathrm{d})\end{array}$ & $\begin{array}{l}\text { かぶり } \\
(\mathrm{mm})\end{array}$ & 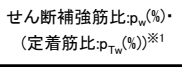 & $\begin{array}{l}\text { 圧縮強度 } \\
\left(\mathrm{N} / \mathrm{mm}^{2}\right) \\
\end{array}$ & \begin{tabular}{|c|c|} 
主鉄筋 \\
腐食率 \\
$(\%)$
\end{tabular} & $\begin{array}{c}\text { せん断補強筋 } \\
\text { 全体 }\end{array}$ & $\begin{array}{c}\text { 5) 平均腐食率 } \\
\text { 下側 }\end{array}$ & $\begin{array}{c}\text { 最大荷重 } \\
(\mathrm{kN}) \\
\end{array}$ & 破壊モード \\
\hline & & \multirow{15}{*}{$\mathrm{pb}$} & $\mathrm{pb}(2.40)-\mathrm{C} 40-\mathrm{Nb}$ & \multirow{5}{*}{2.40} & \multirow{15}{*}{40} & \multirow{15}{*}{$0.00(0.94)$} & 21.5 & 0.0 & & & 111.5 & 斜め引張 \\
\hline & & & $\mathrm{pb}(2.40)-\mathrm{C} 40-\mathrm{Nn}$ & & & & 22.0 & 0.0 & & & 235.6 & 圧壊 \\
\hline & & & $\mathrm{pb}(2.40)-\mathrm{C} 40-\mathrm{CA}^{* 2}$ & & & & 25.7 & 4.7 & & & 184.0 & 定着部上縁 \\
\hline & & & $\mathrm{pb}(2.40)-\mathrm{C} 40-\mathrm{CC}$ & & & & 26.7 & 14.7 & & & 172.3 & 定着部上縁·圧壊 \\
\hline & & & \begin{tabular}{|l|}
$\mathrm{pb}(2.40)-\mathrm{C} 40-\mathrm{CD}$ \\
\end{tabular} & & & & 26.2 & 26.8 & & & 161.1 & 定着部上縁·圧壊 \\
\hline & & & $\mathrm{pb}(3.19)-\mathrm{C} 40-\mathrm{Nb}$ & \multirow{5}{*}{3.19} & & & 22.1 & 0.0 & & & 100.8 & 斜め引張 \\
\hline & & & $\mathrm{pb}(3.19)-\mathrm{C} 40-\mathrm{Nn}$ & & & & 24.3 & 0.0 & & & 123.1 & 厓壊 \\
\hline & & & $\mathrm{pb}(3.19)-\mathrm{C} 40-\mathrm{CA}{ }^{* 2}$ & & & & 25.9 & 4.5 & 未計測 & 未計測 & 106.8 & 圧壊 \\
\hline & & & $\mathrm{pb}(3.19)-\mathrm{C} 40-\mathrm{CC}$ & & & & 25.2 & 20.0 & & & 114.3 & 定着部上縁·圧壊 \\
\hline & & & \begin{tabular}{|l|}
$\mathrm{pb}(3.19)-\mathrm{C} 40-\mathrm{CD}$ \\
\end{tabular} & & & & 22.7 & 26.3 & & & 98.0 & 定着部上縁 \\
\hline & & & $\mathrm{pb}(4.42)-\mathrm{C} 40-\mathrm{Nb}$ & & & & 23.0 & 0.0 & & & 62.8 & 斜め引張 \\
\hline & & & \begin{tabular}{|l}
$\mathrm{pb}(4.42)-\mathrm{C} 40-\mathrm{Nn}$ \\
\end{tabular} & & & & 24.3 & 0.0 & & & 61.4 & 厓壊 \\
\hline & & & $\mathrm{pb}(4.42)-\mathrm{C} 40-\mathrm{CA}^{* 2}$ & 4.42 & & & 24.5 & 5.0 & & & 58.5 & 斜め引張 \\
\hline & & & $\mathrm{pb}(4.42)-\mathrm{C} 40-\mathrm{CB}$ & & & & 25.2 & 12.3 & & & 81.1 & 圧壊 \\
\hline & & & $\mathrm{pb}(4.42)-\mathrm{C} 40-\mathrm{CC}$ & & & & 21.9 & 23.0 & & & 51.6 & 定着部上縁·圧壊 \\
\hline & & & ipb(2.40)-C60-CA & & 60 & & 31.2 & 8.9 & & & 87.0 & 付着割裂 \\
\hline & & & \begin{tabular}{|l}
$\mathrm{ipb}(2.40)-\mathrm{C} 50-\mathrm{CA}$ \\
\end{tabular} & 2.40 & 50 & & 32.4 & 7.1 & & & 94.0 & 付着割裂 \\
\hline & & & \begin{tabular}{|c|}
$\mathrm{ipb}(2.40)-\mathrm{C} 40-\mathrm{CA}$ \\
\end{tabular} & & 40 & & 32.7 & 7.1 & & & 119.5 & 付着割裂 \\
\hline & & & ipb(3.19)-C60-CA & & 60 & & 33.5 & 7.3 & & & 115.5 & 付着割裂 \\
\hline & & $\mathrm{ipb}$ & \begin{tabular}{|l|}
$\mathrm{ipb}(3.19)-\mathrm{C} 50-\mathrm{CA}$ \\
\end{tabular} & 3.19 & 50 & & 34.5 & 7.3 & & & 103.0 & 付着割裂 \\
\hline & & & \begin{tabular}{|l}
$\mathrm{ipb}(3.19)-\mathrm{C} 40-\mathrm{CA}$ \\
\end{tabular} & & 40 & & 32.2 & 8.1 & & & 62.5 & 付着割裂 \\
\hline & & & \begin{tabular}{|l|}
$\mathrm{ipb}(4.42)-\mathrm{C} 60-\mathrm{CA}$ \\
\end{tabular} & & 60 & & 33.5 & 6.4 & & & 62.5 & 付着割裂 \\
\hline & & & \begin{tabular}{|l|}
$\mathrm{ipb}(4.42)-\mathrm{C} 50-\mathrm{CA}$ \\
\end{tabular} & 4.42 & 50 & & 34.5 & 6.8 & & & 50.5 & 付着割裂 \\
\hline & & & \begin{tabular}{|l|}
$\mathrm{ipb}(4.42)-\mathrm{C} 40-\mathrm{CA}$ \\
\end{tabular} & & 40 & & 35.6 & 7.0 & & & 53.0 & 斜め引張 \\
\hline & & & L-SS-0 & & & & 27.0 & 0.0 & 0.0 & 0.0 & 91.3 & 曲げ \\
\hline & & & L-SS-5 & & & $033(035)$ & 29.6 & 3.7 & 17.2 & 13.0 & 77.0 & 曲げ \\
\hline & & ss & L-SS-10 & & & $0.33(0.35)$ & 26.5 & 14.8 & 62.6 & 63.4 & 57.9 & 曲げ \\
\hline & & & L-SS-20 & & & & 27.2 & 18.3 & 73.7 & 57.4 & 56.7 & 曲げ \\
\hline & & SE & L-SF-10 & & & & 31.8 & 11.5 & 28.4 & 26.2 & 73.2 & 定着部上縁 \\
\hline & & SF & L-SF-20 & & & & 34.2 & 21.3 & 28.2 & 23.7 & 68.9 & 曲げ \\
\hline & L & & L-S2-0 & 4.53 & & & 30.3 & 0.0 & 0.0 & 0.0 & 91.4 & 曲げ \\
\hline & & SA & L-S2-10 & & & $0.00(0.35)$ & 30.4 & 10.1 & 39.2 & 28.8 & 69.8 & 付着割裂 \\
\hline & & $S A$ & L-S2-10ub & & & & 30.1 & 11.3 & 0.0 & 0.0 & 52.9 & $\begin{array}{l}\text { 付着割裂 } \\
\end{array}$ \\
\hline & & & L-S2-20 & & & & 28.0 & 16.4 & 42.6 & 21.4 & 59.2 & 付着割裂 \\
\hline & & & L-S0-0 & & & & 30.8 & 0.0 & & & 94.9 & 曲げ \\
\hline & & so & L-S0-10 & & & & 31.6 & 10.2 & & & 53.1 & 付着割裂 \\
\hline 曲げ破壞型 & & & L-S0-20 & & 40 & & 35.5 & 18.6 & 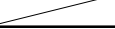 & & 34.3 & 付着割裂 \\
\hline & & & $\mathrm{H}-\mathrm{SS}-0$ & & & & 29.6 & 0.0 & 0.0 & 0.0 & 100.2 & 曲け゚ \\
\hline & & ss & $\mathrm{H}-\mathrm{SS}-10$ & & & $0.27(0.40)$ & 30.7 & 9.7 & 35.3 & 32.2 & 83.5 & 曲げ \\
\hline & & & $\mathrm{H}-\mathrm{SS}-20$ & & & & 30.8 & 20.0 & 58.3 & 70.8 & 63.0 & 曲げ \\
\hline & & $\mathrm{SF}$ & $\mathrm{H}-\mathrm{SF}-10$ & & & - & 31.6 & 13.1 & & & 76.1 & 曲げ \\
\hline & & & $\mathrm{H}-\mathrm{S} 2-10$ & & & 000040 & 27.8 & 7.4 & 29.9 & 18.3 & 85.9 & 付着割裂 \\
\hline & $\mathrm{H}$ & & $\mathrm{H}-\mathrm{S} 2-20$ & 330 & & $0.00(0.40)$ & 30.3 & 18.2 & 27.3 & 27.2 & 72.4 & 付着割裂 \\
\hline & $\mathrm{H}$ & SA & $\mathrm{H}-\mathrm{S} 3-20$ & 3.30 & & $0.00(0.60)$ & 33.1 & 12.3 & 10.5 & 12.5 & 74.9 & 付着割裂 \\
\hline & & & $\mathrm{H}-\mathrm{S} 4-20$ & & & $0.00(0.81)$ & 37.8 & 16.0 & 10.3 & 23.8 & 64.4 & 付着割裂 \\
\hline & & & $\mathrm{H}-\mathrm{SO}-0$ & & & & 30.4 & 0.0 & & & 101.1 & 曲け゚ \\
\hline & & & $\mathrm{H}-\mathrm{SO}-10$ & & & & 30.9 & 10.8 & & & 80.7 & 付着割裂 \\
\hline & & so & $\mathrm{H}-\mathrm{SO}-20 \mathrm{~A}$ & & & & 30.8 & 19.0 & & & 75.4 & 付着割裂 \\
\hline & & & $\mathrm{H}-\mathrm{S} 0-20 \mathrm{~B}$ & & & & 33.9 & 20.9 & & & 39.9 & 付着 \\
\hline $1 \quad p_{w}(\%)$ & & $\left(b_{w} \cdot s\right)$ & $A_{w}[\mathrm{~m}$ & :一組 & 䉼 & 断面積 & 式験体 & 刀幅 & [mm]: せ & 筋の間队 & & \\
\hline $\begin{array}{c}p_{T w}(\%)= \\
\text { 鉄筋ひ- }\end{array}$ & $=A_{T w}$ & $\cdot n /\left(b_{w}\right.$ & 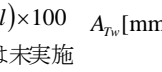 & $\left.\mathrm{n}^{2}\right]$ : 一組 & 筋 & $n$ :定齐 & $l[\mathrm{~mm}$ & ]: 試馬 & 本端部か & での & & \\
\hline
\end{tabular}


表ー2 コンクリートの配合

(a) ipb試験体

\begin{tabular}{|c|c|c|c|c|c|c|c|c|}
\hline \multirow{3}{*}{$\begin{array}{l}\text { Gmax } \\
(\mathrm{mm})\end{array}$} & \multirow{3}{*}{$\begin{array}{l}\text { W/C } \\
(\%)\end{array}$} & \multirow{3}{*}{$\begin{array}{c}\text { スランプ } \\
(\mathrm{cm})\end{array}$} & \multirow{3}{*}{$\begin{array}{c}\text { 空気量 } \\
(\%)\end{array}$} & \multicolumn{5}{|c|}{ 単位量 $\left(\mathrm{kg} / \mathrm{m}^{3}\right)$} \\
\hline & & & & 水 & セメント & 細骨材 & 粗骨材 & \\
\hline & & & & $\mathrm{W}$ & $\mathrm{C}$ & $S$ & $G$ & 纰朴 \\
\hline 25 & 60 & 10 & 5.0 & 169 & 282 & 810 & 1009 & 2.82 \\
\hline
\end{tabular}

(b) その他試験体

\begin{tabular}{|c|c|c|c|c|c|c|c|c|}
\hline \multirow{3}{*}{$\begin{array}{l}\text { Gmax } \\
(\mathrm{mm})\end{array}$} & \multirow{3}{*}{$\begin{array}{l}\text { W/C } \\
(\%)\end{array}$} & \multirow{3}{*}{$\begin{array}{c}\text { スランプ } \\
(\mathrm{cm})\end{array}$} & \multirow{3}{*}{$\begin{array}{c}\text { 空気量 } \\
(\%)\end{array}$} & \multicolumn{5}{|c|}{ 単位量 $\left(\mathrm{kg} / \mathrm{m}^{3}\right)$} \\
\hline & & & & 水 & セxント & 細骨材 & 粗骨材 & \\
\hline & & & & W & C & s & G & \\
\hline 20 & 60 & 10 & 5.0 & 168 & 280 & 826 & 996 & 2.80 \\
\hline
\end{tabular}
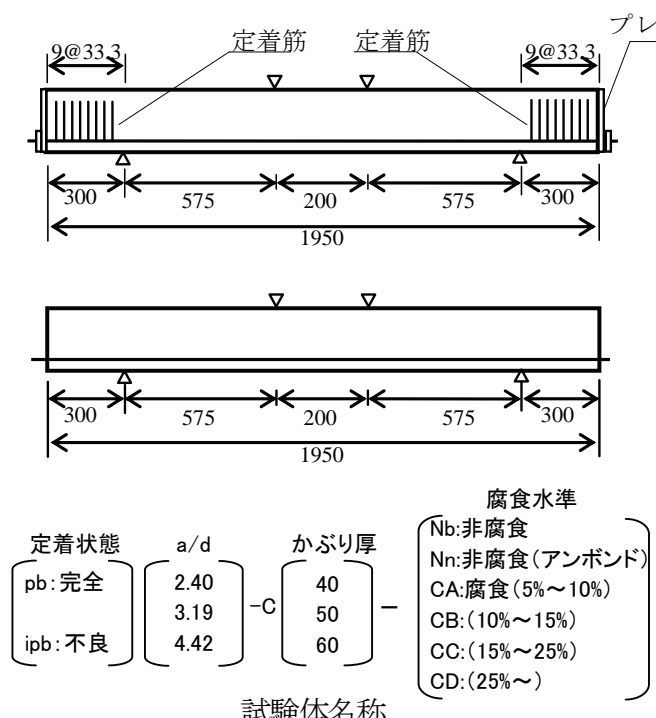

図-1 試験体概要（せん断破壊型）
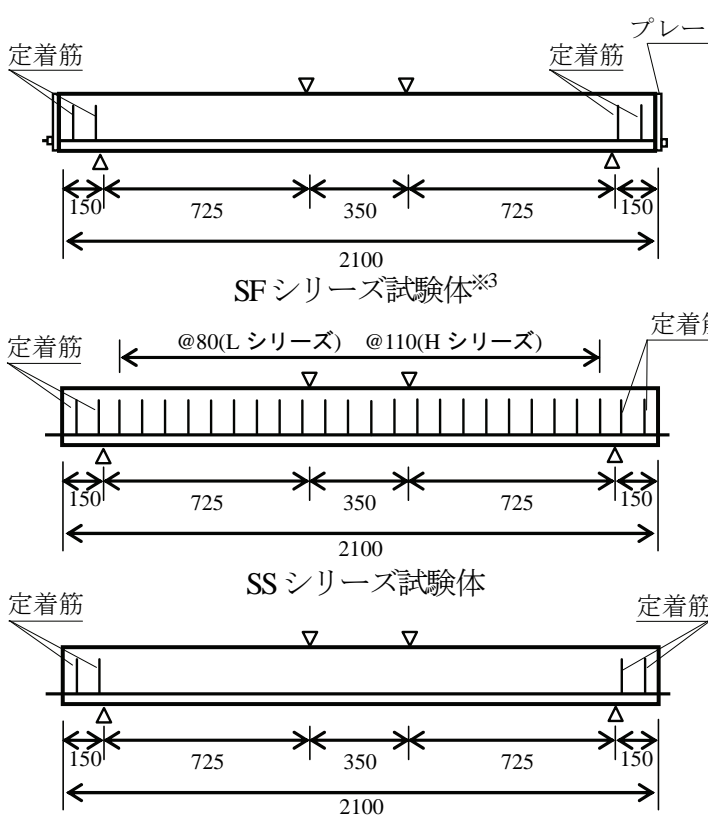

SA シリーズ試験体

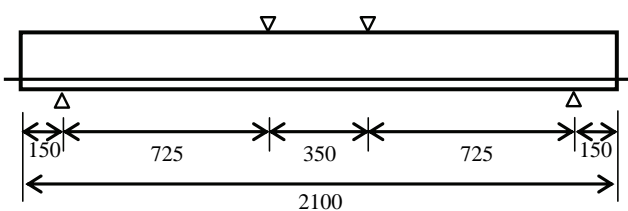

SO シリーズ試験体

図-2＼cjkstart試験体概要（曲げ破壊型）
表－3 鉄筋の材料試験結果

\begin{tabular}{|c|c|c|c|c|}
\hline 鉄筋径 & 規格 & $\begin{array}{c}\text { 公称断面積 } \\
\left(\mathrm{mm}^{2}\right)\end{array}$ & $\begin{array}{l}\text { 降伏応力 } \\
\left(\mathrm{N} / \mathrm{mm}^{2}\right)\end{array}$ & $\begin{array}{l}\text { 引張強度 } \\
\left(\mathrm{N} / \mathrm{mm}^{2}\right)\end{array}$ \\
\hline $\mathrm{D} 22$ & \multirow{2}{*}{ USD685B } & 387.1 & 723 & 930 \\
\hline D19 & & 286.5 & 716 & 901 \\
\hline $\mathrm{D} 16$ & \multirow{2}{*}{ SD295A } & 198.6 & 369 & 523 \\
\hline D6 & & 31.7 & 438 & 557 \\
\hline
\end{tabular}

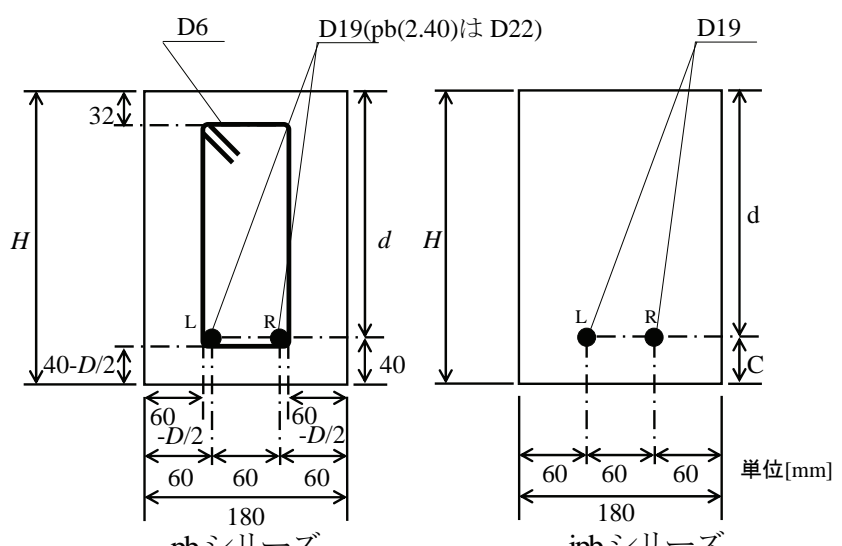

pbシリーズ

ipbシリーズ
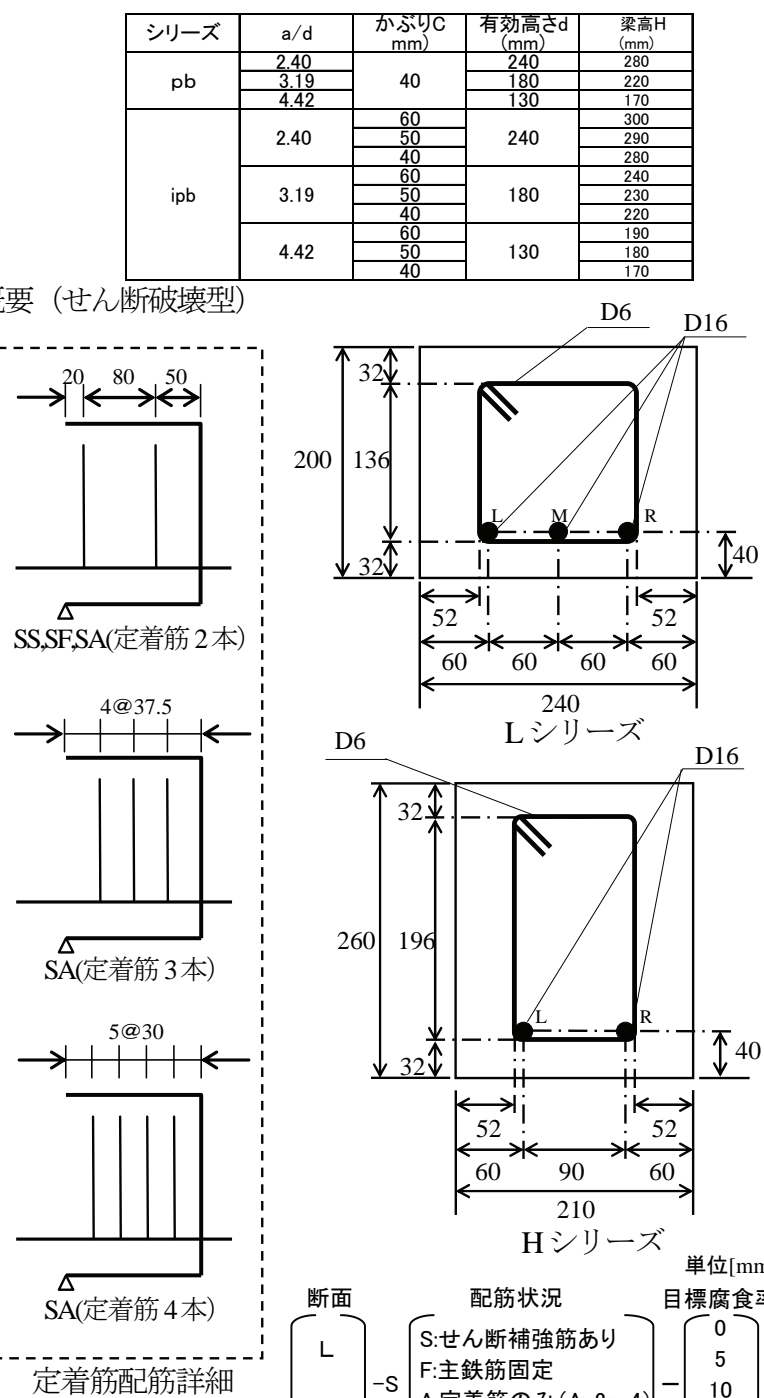

D6

Lシリーズ D16

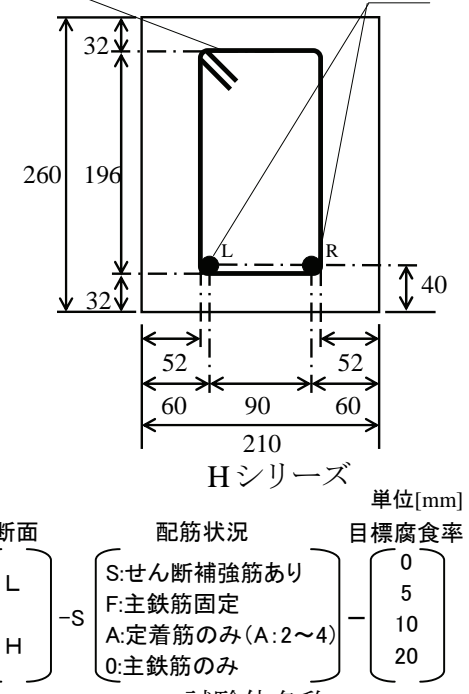

試験体名称

※3H-SFシリーズは定着筋なし 
別すると，せん断破壊型部材と曲け破壊型部材に分けら れる．前者は主に鉄筋腐食劣化したRC部材のせん断耐 力評価に用い，後者は曲げ耐力評価に用いる．なお，曲 げ破壊型部材の載荷試験結果の一部は既報済みである ${ }^{14)}$ 試験体のコンクリートの配合は表一2, 鉄筋の材料試 験結果は表一3に示寸通りである。

\section{（1）試験体概要および実験パラメータ（せん断破壊型）}

\section{a) 完全定着試験体 (pb シリーズ)}

試験体の概要を図一1に示す，試験体の断面寸法は, 梁高は170mm, 220mm, 280mmの3種類であり，断面幅 は全て180mmである.

主鉄筋には，曲げ引張破壊を避けるため, 高張力ネ ジフシ鉄筋（D19）を用いた。 なお， $a / d=2.40$ 試験体に はD22を用いた。最小かぶり厚（芯かぶり）は40mmで ある. 完全定着試験体では，主鉄筋端部の引き込みを防 止するため，支点外側の領域に補強筋（以下，定着筋と 称する）を配筋した．さらに試験体端面にプレートを設 置し，ナットを用いて主鉄筋とプレートを固定した．後 に詳述するが，本研究では試験体端面から支点の内側 $100 \mathrm{~mm}$ までの領域を定着領域と称することとする.

完全定着試験体の実験パラメータはa/d(せん断スパン 比）および主鉄筋の腐食率である，a/dは，2.40，3.19お よび4.42の3水準であり, せん断スパンは一定 $(575 \mathrm{~mm})$ と し，有効高さのみが試験体シリーズで異なる.

主鉄筋の腐食率は0〜30\%の範囲内で4水準とした。さ らに，支点間の主鉄筋の節をろうで埋め, ビニールテー プを巻き付け，グリスを塗布することでアンボンド処理 を施した試験体を各a/dにつき 1 体作成した.

\section{b) 不完全定着試験体（ipbシリーズ）}

試験体の概要を図一1に示す，不完全定着試験体の断 面の形状寸法は完全定着試験体（pbシリーズ）と同様で あり，主鉄筋に使用した鉄筋は高張力ネジフシ鉄筋 (D19)である.

不完全定着試験体では，支点外側の領域において定 着筋による定着補強およびプレートによる主鉄筋の固定 は行っていない，実験パラメータは，a/dおよびかぶり 厚であり，a/dは完全定着試験体と同様の3水準，かぶり 厚は40mm，50mmおよび60mmの3水準とした。.また，目 標とする主鉄筋の腐食率は5\%とした，なお，図一1に示 すように, 各試験体の名称は試験体パラメータの概略を 示している.

\section{（2）試験体概要および実験パラメータ（曲げ破壊型）}

試験体の形状寸法およひ配筋を図一2 に示寸。試験体 の断面諸元は 2 種類であり，Lシリーズは幅 $240 \mathrm{~mm}$, 梁 高 200mm，H シリーズは幅 210mm，梁高 260mm である. 両シリーズともに主鉄筋端部の定着不良を想定し，支点

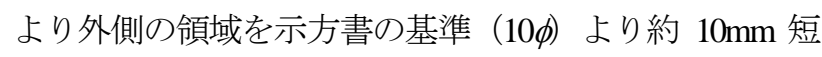
い150mmに設定した.

主鉄筋には D16 異型鉄筋(SD295A)を使用し，主鉄筋比 はLシリーズが 1.55\%，Hシリーズが 0.86\%である.

せん断補強筋を配筋する試験体では，D6 異型鉄筋 (SD295A)を使用し，その間隔は有効高さの $1 / 2$ とした (Lシリーズは 80mm 間隔，Hシリーズは $110 \mathrm{~mm}$ 間隔)。 Lシリーズおよび Hシリーズの実験パラメータは, 主 鉄筋の腐食レベル, せん断補強筋の有無, 定着筋量など により, さらに 4 つの試験体シリーズ（SF シリーズ, SS シリーズ, SA シリーズ, S0 シリーズ）に分類される. 各試験体シリーズにおける主鉄筋の目標平均腐食率は 0 〜20\%の範囲内とした. なお, 試験体名称は, 図一2に 示すように試験体パラメータの概略を示している.

SF シリーズは，主鉄筋をプレートとナットを用いて， 試験体端部に固定した試験体であり，前述したせん断破 壊型の完全定着試験体に相当する.

SS シリーズは，せん断補強筋ならびに定着筋を有す る試験体である。なお， SF シリーズを除く試験体シリ ーズでは，試験体端部で主鉄筋を固定していない．

SA シリーズは，定着筋のみを配筋した試験体シリー ズである. L-SA シリーズでは配筋する定着筋を 2 本と し，目標腐食率は $0 \% ， 10 \%$ おび 20\%の 3 水準とした。 また, 定着筋にアンボンド処理を施した試験体 L-SO10ub を作成した. H-SA シリーズでは主鉄筋の目標平均 腐食率 $10 \%$ とした試験体では，定着筋を 2 本配筋した. 目標腐食率を $20 \%$ とした試験体では，定着筋の本数を 2 本，3本，4本と変化させた。

$\mathrm{S} 0$ シリーズは，主鉄筋のみを有する試験体シリーズ であり，目標平均腐食率は 0 20\%の範囲内である．な お，H-SO シリーズにおいて目標腐食率を 20\%に設定し た試験体は 2 体作成し，それぞれ H-SO-20A，H-SO-20B と称する.

\section{（3）腐食試験手法}

鉄筋の腐食手法は，比較的早期に設定した腐食率が 得られ，その制御が容易である電食試験法を採用した ${ }^{14}$. せん断破懐型の試験体において, 完全定着試験体(pb シリーズ)は，主鉄筋の端部定着を確保するため，支点 間の鉄筋のみを促進腐食した. 不完全定着試験体(ipbシ リーズ)では，はり全長にわたり，鉄筋を促進腐食した。 曲げ破壊型の試験体では，全ての試験体をはり全長に わたり鉄筋を促進腐食した.

載荷試験終了後, 主鉄筋および各種補強筋は, 試験体 からはつり出し, $10 \%$ 濃度 $\left(20^{\circ} \mathrm{C}\right)$ のクエン酸二アンモ ニウム溶液に 24 時間浸漬して腐食生成物を除去した.

L-S0 シリーズ試験体では，定着，せん断，等曲げ区間 から $100 \mathrm{~mm}$ 鉄筋を切り出して質量を計測し, 腐食前後 


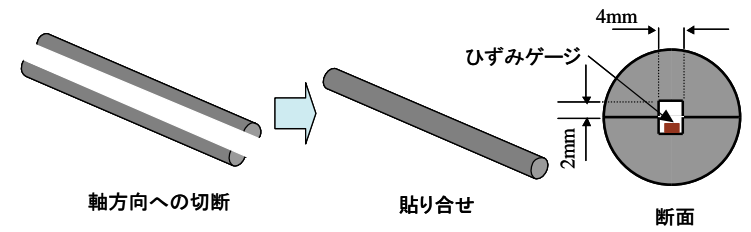

図-3 貼り合わせ鉄筋概要

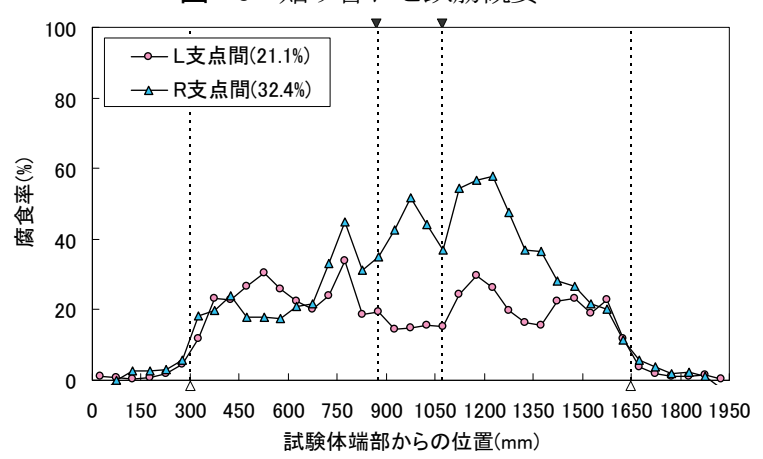

(a) 腐食率分布

(b) かぶりコンクリート”(底面) の腐食ひび割れ性状 図-4 腐食性状(試験体 pb(2.40)-C40-CD)

の質量減少率（腐食率）を算出した。なお，腐食試験以 前の鉄筋の質量は配筋の前に事前に計測した值を用い， 単位長さあたりの質量は一定と仮定した．ipb シリーズ では，主鉄筋を $100 \mathrm{~mm}$ 間隔に切断し腐食率を計測した。 それ以外の試験体シリーズでは，主鉄筋を $50 \mathrm{~mm}$ 間隔に 切断し腐食率を計測した.

せん断補强筋および定着筋は, 全体の腐食率に加えて, 主鉄筋重心位置から下側の領域の腐食率を計測した ${ }^{14}$.

なお，pb シリーズ試験体の定着筋については，腐食 率の計測を実施していない.

\section{（4）載荷方法および測定項目}

載荷は変位制御 $(0.5 \mathrm{~mm} / \mathrm{min})$ で行い，静的2点集中載 荷による曲げ載荷試験である（図ー1，図一2参照）。

測定項目は，鉄筋の腐食率，腐食ひび割れ幅，スパ ン中央部のたわみおよび鉄筋の軸方向ひずみである，な お，一部の試験体は鉄筋の軸方向ひず夕を計測していな い.

鉄筋の軸方向ひずみの測定に関しては，ひずみゲー ジの貼り付け位置は鉄筋内部とし，図一3に示すように 鉄筋を軸方向に切断した後， その断面に $2 \times 4 \mathrm{~mm}$ の溝を 掘り，ひずみゲージ（検長 $2 \mathrm{~mm} ）$ を48mm間隔(ipbシリ ーズは50mm)で貼り付けた。

ひずみゲージのリード線は，鉄筋内の溝を這わせて， 端部から取り出した. その後, 2対の切断された鉄筋を エポキシ樹脂接着剤により接合し一本の鉄筋とした. 載 荷試験終了後に, 鉄筋をはつり出し, 目視観察の結果, 接合面における剥離やずれは認められなかったことから， 一本の鉄筋として機能しているものと判断される.

\section{3. 主鉄筋の付着伝達機構とせん断耐荷性状}

(1) 完全定着試験体（pb シリーズ）

a) 腐食劣化性状

各試験体の鉄筋腐食率を表一1に示寸，表中の腐食率は は，区間毎に計測した腐食率の平均值である。なお， $\mathrm{pb}$ シリーズ腐食試験体の腐食率はスパン内の平均值である. いずれの腐食試験体も主鉄筋全体の平均腐食率は，ほぼ 目標值に近い值を示している. 図一4に腐食率分布の一 例を示すように，スパン内のみ鉄筋を促進腐食したこと から, 支点外側の領域の腐食率はスパン内に比べて非常 に小さい. また, いずれの試験体もかぶりコンクリート には，鉄筋に沿って腐食ひび割れが発生し，錆汁の漏出 も確認された. また, 腐食ひび割れ先端は支点外側の領 域にまで到達した。 この要因としては, 支点外側の領域 においても若干の腐食が発生したことおよび支点内に発 生した腐食ひび割れの伝播が考えられる.

\section{b）載荷試験結果}

図ー5 7にpbシリーズ試験体の破壊ひび割れ性状, 図 -8に荷重と中央変位の関係を示寸. $a / d=2.40$ の場合, 非 腐食試験体の破壊モードは斜め引張破壊であった。これ に対して，アンボンド試験体では，支点内の付着が無い ことから，等曲げ区間に数本の曲げひび割れが発生した 後, はり上縁コンクリートの圧壊により，はりは，破壊 に至った。 また，後に詳述するようにアンボンド試験体 では，主鉄筋は未降伏であることから破壊モードは曲げ 圧縮破壊であると判断される。

一方，腐食試験体においては，a/d=2.40では，いずれ の腐食試験体も斜めひび割れが非腐食試験体比べて載荷 点よりに発生した後, 鉄筋軸に沿った水平ひび割れが発 生したが，支点付近で停止した。 これは，pbシリーズ試 験体では，試験体端面でプレートとナットにより主鉄筋 端部の引き込みを拘束したことによる. 水平ひび割れが 支点付近まで進展した後, 支点上縁コンクリートに曲げ ひび割れが発生し，荷重は徐々に低下した。 $a / d=3.19 お ~$ よび $a / d=4.42$ 腐食試験体においても同様の傾向を示した. 定着上縁に曲げひび割れが発生したメカニズムを以下 に考察する. 支点間の付着が損失したことにより，支点 内の鉄筋とコンクリートには相対ずれが生じる. 一方, 支点外側では鉄筋とコンクリートの付着が健全であるこ とに加えて鉄筋端部のプレート固定によって，この相対 ずれを拘束する復元力が働く．この復元力により支点近 傍の上縁コンクリートに曲げ応力が発生し, 定着部上縁 のコンクリートに曲げひび割れが発生したことで，鉄筋 力を保持することが出来なくなり，はりは破壞に至った ものと判断される. 腐食試験体においてのみ定着上縁破 壊を生じたことは，定着筋に沿った腐食ひび割れが発生 したため，負曲げに対する抵抗力が低下していたことが 


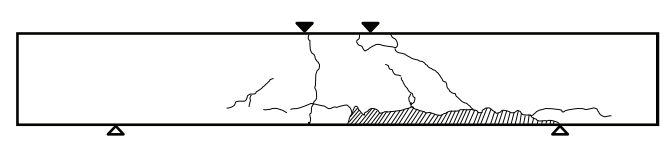

(a) $\mathrm{pb}(2.40)-\mathrm{C} 40-\mathrm{Nb}(0.0 \%)$

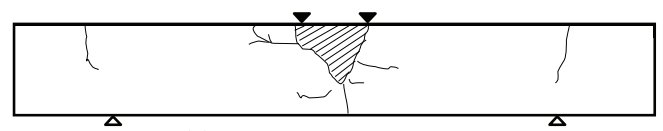

(b) $\mathrm{pb}(2.40)-\mathrm{C} 40-\mathrm{Nn}(0.0 \%)$

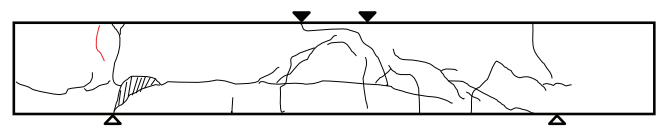

(c) $\mathrm{pb}(2.40)-\mathrm{C} 40-\mathrm{CA}(4.7 \%)$

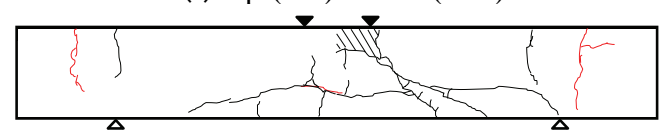

(d) $\mathrm{pb}(2.40)-\mathrm{C} 40-\mathrm{CC}(14.7 \%)$

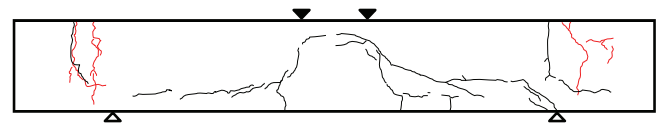

(e) $\mathrm{pb}(2.40)-\mathrm{C} 40-\mathrm{CD}(26.8 \%)$

（ ）内の数值は主鉄筋の平均腐食率 一破壊ひび割れ 一腐食ひび割れ

図－5＼cjkstart破壊ひび割れ性状(pbシリーズ : a/d=2.40)

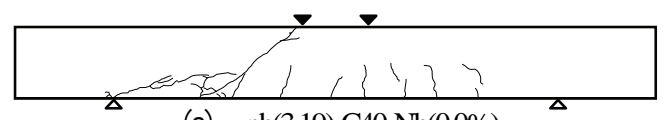

(a) $\mathrm{pb}(3.19)-\mathrm{C} 40-\mathrm{Nb}(0.0 \%)$

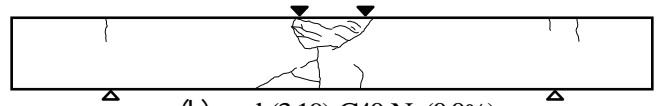

(b) $\mathrm{pb}(3.19)-\mathrm{C} 40-\mathrm{Nn}(0.0 \%)$

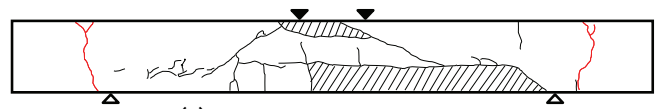

(c) $\mathrm{pb}(3.19)-\mathrm{C} 40-\mathrm{CA}(4.5 \%)$

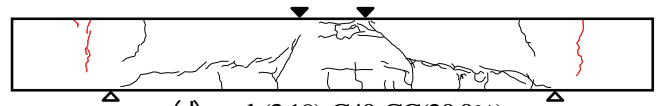

(d) $\mathrm{pb}(3.19)-\mathrm{C} 40-\mathrm{CC}(20.0 \%)$

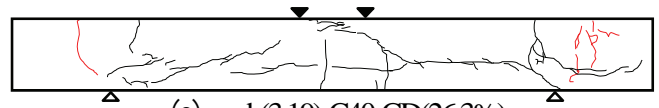

(e) $\quad \mathrm{pb}(3.19)-\mathrm{C} 40-\mathrm{CD}(26.3 \%)$

（）内の数值は主鉄筋の平均腐食率 一破壊ひび割れ 一腐食ひひ割れ 図ー6＼cjkstart破壊ひび割れ性状 (pbシリーズ : $a / d=3.19)$
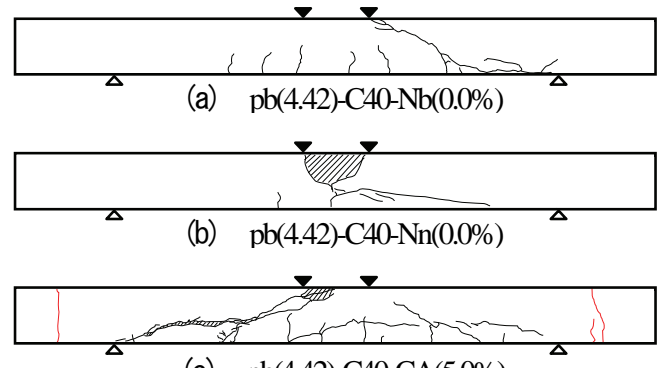

(c) $\mathrm{pb}(4.42)-\mathrm{C} 40-\mathrm{CA}(5.0 \%)$
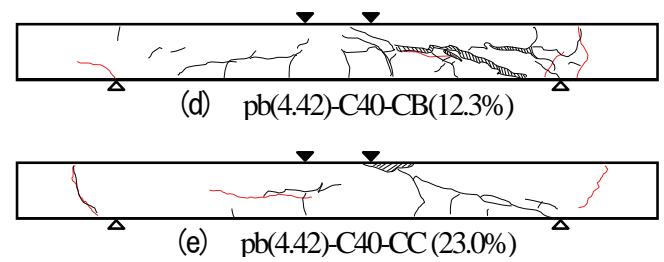

（ ）内の数值は主鉄筋の平均腐食率 一破壊ひひ割れ 一腐食ひび割れ

図-7 破壊ひび割れ性状(pbシリーズ : a/d=4.42)

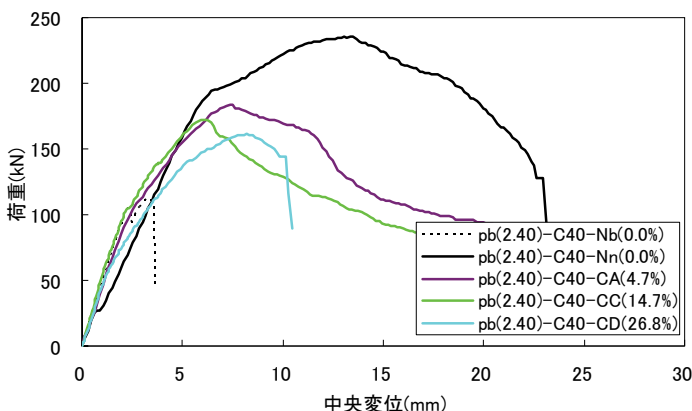

(a) $a / d=2.40$

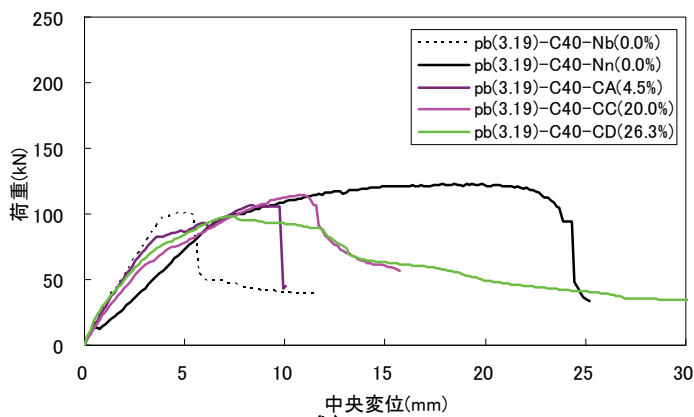

(b) $a / d=3.19$

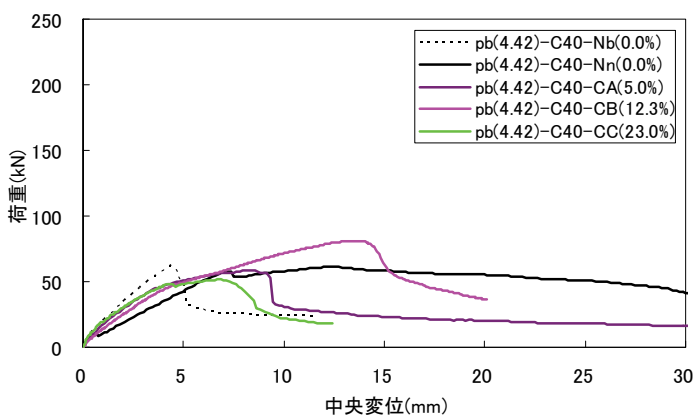

(c) $a / d=4.42$

図-8 荷重と中央変位 (pbシリーズ)

要因として考えられる.

また，試験体 pb(2.40)-C40-CC, pb(2.40)-C40-CD， pb(3.19)-C40-CC，pb(4.42)-C40-CBおよびpb(4.42)-C40-CCは 定着上縁に曲げひび割れが発生していたことに加えて, 載荷点近傍のコンクリート，或いはウェブコンクリート の圧壊が確認された。これら試験体については, 両者の 複合的な影響で破壊に至ったと考えられる（定着部上 縁・圧壊と称寸る）。

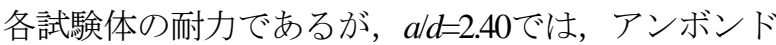
試験体の耐力は付着を有寸る試験体 $\mathrm{pb}(2.40)-\mathrm{C} 40-\mathrm{Nb}$ の耐 力に比べて約120kN増加した. 腐食試験体の耐力につい ても非腐食試験体の耐力に比べて大きい．また，その耐 力は，腐食率の増加に伴い耐力は低下寸る傾向を示した. $a / d=3.30$ の場合では，アンボンド試験体および腐食試 験体の耐力は，非腐食試験体と比較して大きいものの, $a / d=2.40$ に比べて非腐食時からの耐力増加は小さい。 ま た，腐食試験体の耐力は $a / d=2.40$ の場合と同様，腐食率 の増加に伴い低下寸る傾向が認められた.

$a / d=4.42$ の場合については耐力の増加は認められず, a/dが大きいスレンダーなはりでは，アーチ而荷機構の 


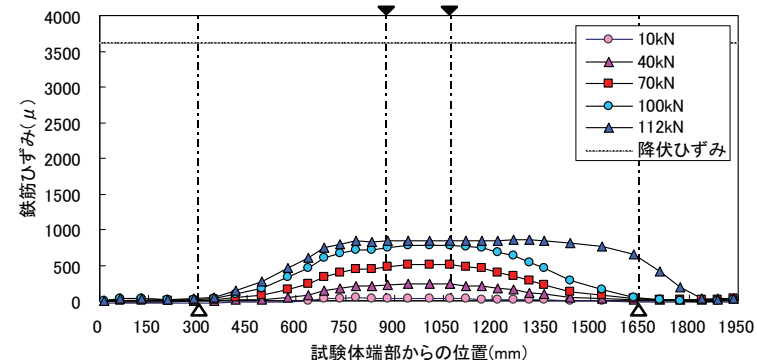

(a) $\mathrm{pb}(2.40)-\mathrm{C} 40-\mathrm{Nb}$

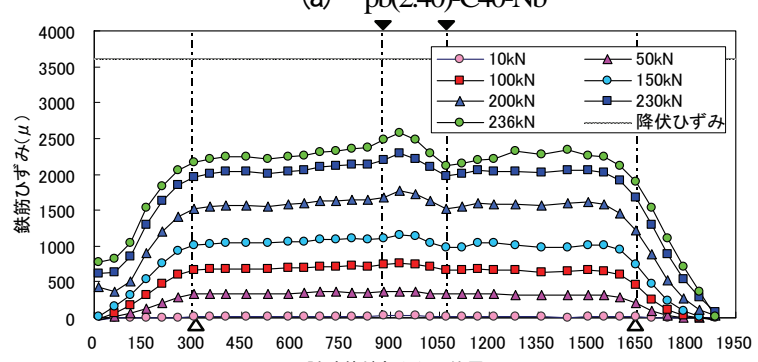

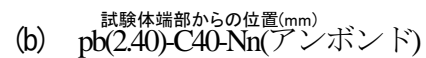

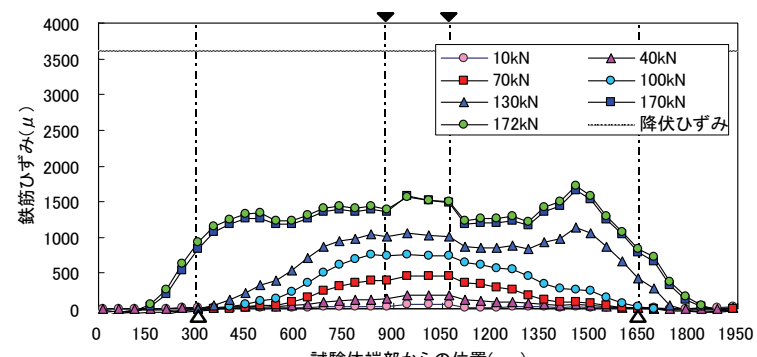

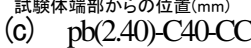

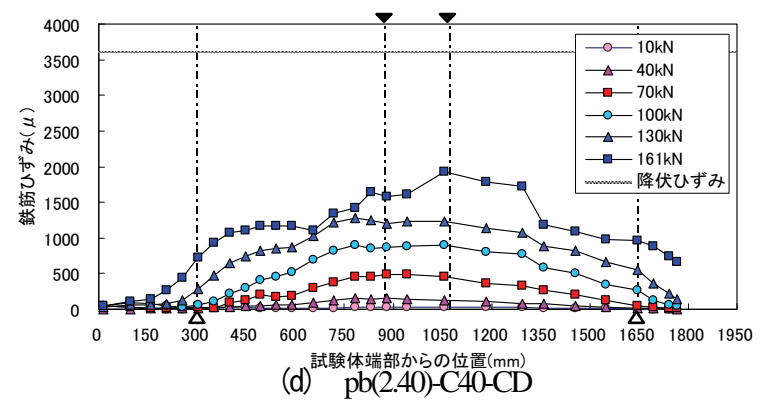

図一9 鉄筋ひずみ分布 $(\mathrm{pb}$ シリーズ $\mathrm{a} / \mathrm{d}=2.40)$

形成による耐力増加は期待できないと考えられる.

図一9に一例として $a / d=2.40$ の試験体の各荷重レベル時 の鉄筋ひずみ分布を示す．図一9(a)に示すように，非腐 食試験体pb(2.40)-C40-Nbにおいては，スパン内の付着が 十分に機能していることから終局直前まで支点外の領域 にひずみはほとんど生じていない.

一方，アンボンド試験体では，スパン内において，付 着が無いためひずみが一様化している.これにより支点 外の領域まで比較的大きな荷重が伝達され，載荷当初か ら同領域内にひずみが発生している.

図一9(c)，（d) に示寸腐食試験体については, 荷重レ心゙ ルが小さい段階では, 非腐食試験体と同様,ひずみ分布は 上に凸の放物的な分布を示しており, 支点外の領域まで 荷重伝達はなされていない. しかしながら, 荷重が増加 するにしたがい, スパン内のひずみ勾配は緩やかとなり，

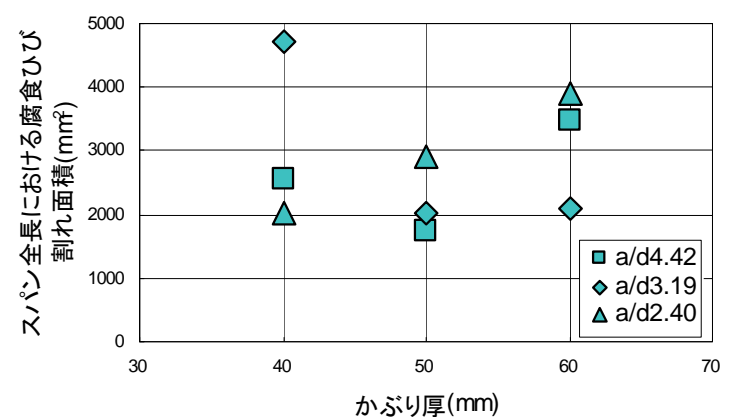

図ー10 かぶり厚と腐食ひび割れ面積

最終的にはアンボンド試験体と同様，スパン内の鉄筋ひ ずみは，ほぼ一様になるとともに，支点の内側約 $100 \mathrm{~mm}$ から端部に向ってひずみ勾配が急となっている。これは, 荷重の載荷に伴ってスパン内で付着切れが生じ, 試験体 端部から支点内側約100mmまでの領域（定着領域）にお いて鉄筋力を保持していると考えられる.このことは $a / d=3.19$ おび $a / d=4.42$ についても同様の傾向であった.

上述の鉄筋ひずみ分布から, 各試験体の終局耐力につ いて考察を行うと，アンボンド試験体に加えて鉄筋腐食 試験体は，終局時には，支点内の付着は消失しており， 梁機構によるせん断抵抗は，ほとんど期待できないもの と思われる，その一方で，支点内の付着が損失したこと により，斜めひび割れが載荷点に近づき，その上方に圧 縮ストラットが形成され，アーチ機構によってせん断力 の大部分に抵抗したと考えられる. また，アーチ機構の 形成による耐力増加には a/d が大きく影響しており，a/d が大きくなる程，而力増加は期待できないと考えられる.

\section{（2）不完全定着試験体（ipb 試験体）}

\section{a）腐食劣化性状}

各試験体の主鉄筋の平均腐食率を表一1に示す．いず れの腐食試験体も主鉄筋全体の平均腐食率は，ほぼ目標 值に近い值を示している，全ての試験体において，底面 のかぶりコンクリートには鉄筋に沿った腐食ひび割れが はり全長にわたり発生した。 また，試験体ipb(2.40)-C60CAおよび試験体ipb(3.19)-C60-CAにおいては底面と側面 のかぶり厚が同じであるため, 側面の一部にも鉄筋に沿 って腐食ひび割れが発生した。

ipbシリーズ試験体のかぶり厚と，はり全長における 腐食ひび割れ面積の関係を図ー10に示す。ここで，腐食 ひび割れ面積とは，かぶりコンクリートに発生した腐食 ひび割れ幅を10cm毎に2か所計測し，その平均值とひび 割れ長さを乗じた值の総和である. 図一10より，かぶり 厚と腐食ひび割れ面積に明確な相関は認められない。

一般に，かぶり表面に腐食ひび割れが発生する時点で の腐食率はかぶり厚が大きい程大きい，一方，河村らは， 腐食ひび割れ幅は，鉄筋近傍から表面に向って大きくな り, 同腐食量時点のひび割れ角度は，かぶりによらず一 


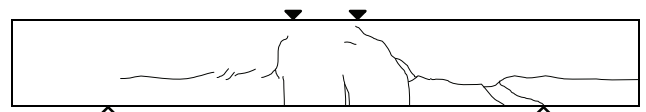

(a) $\operatorname{ipb}(2.40)-C 40-C A(7.1 \%)$

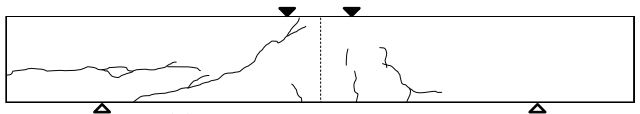

(b) $\operatorname{ipb}(2.40)-\mathrm{C} 50-\mathrm{CA}(7.1 \%)$

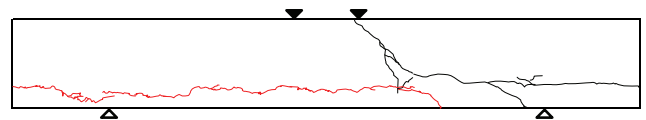

(c) $\quad \operatorname{ipb}(2.40)-C 60-\mathrm{CA}(8.9 \%)$

（）内の数值は主鉄筋の平均腐食率 一破壊ひひ割れ 一 腐食ひび割れ 図ー11 破壊ひび割れ性状(ipbシリーズ : a/d=2.40)

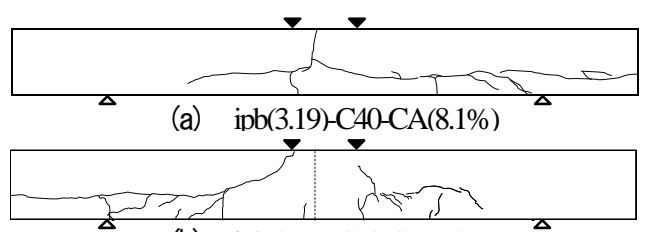

(b) $\operatorname{ipb}(3.19)-C 50-C A(7.3 \%)$

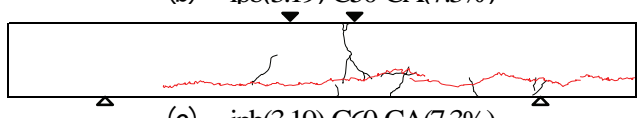

(c) $\quad$ ipb(3.19)-C60-CA(7.3\%)

（）内の数值は主鉄筋の平均腐食率 一一破壊ひび割れ 一 腐食ひび割れ

図-12 破壊ひび割れ性状(ipb シリーズ : a/d=3.19)

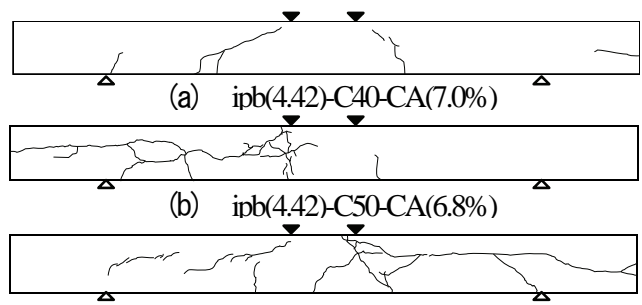

(c) $\quad$ ipb(4.42)-C60-CA(6.4\%)

（ ）内の数值は主鉄筋の平均腐食率 一破壊ひび割れ 一 腐食ひび割れ

図-13 破壊ひび割れ性状(ipb シリーズ : $a / d=4.42$ )

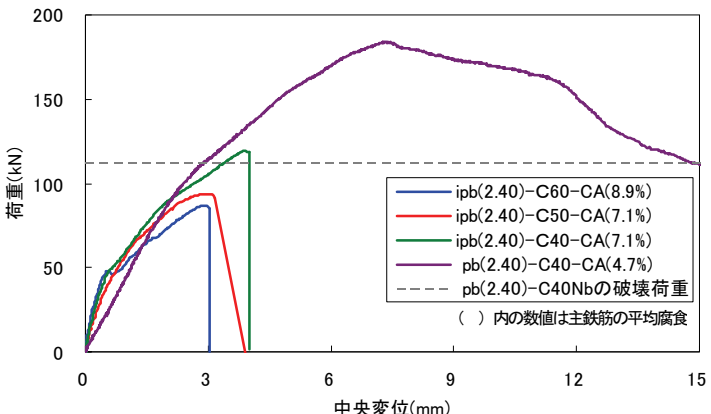

(a) $a / d=2.40$

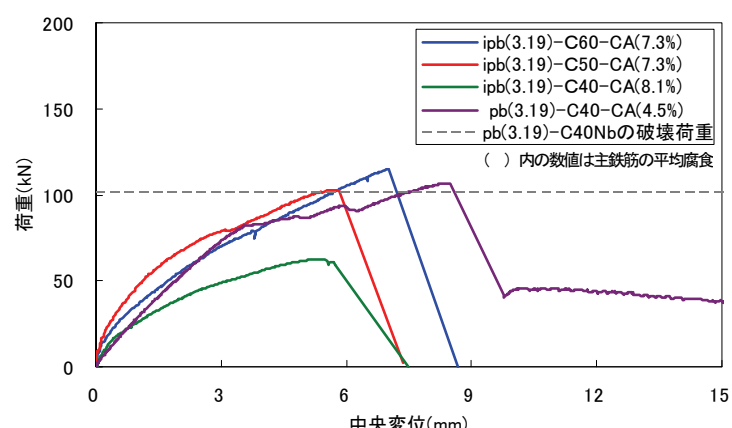

(b) $a / d=3.19$

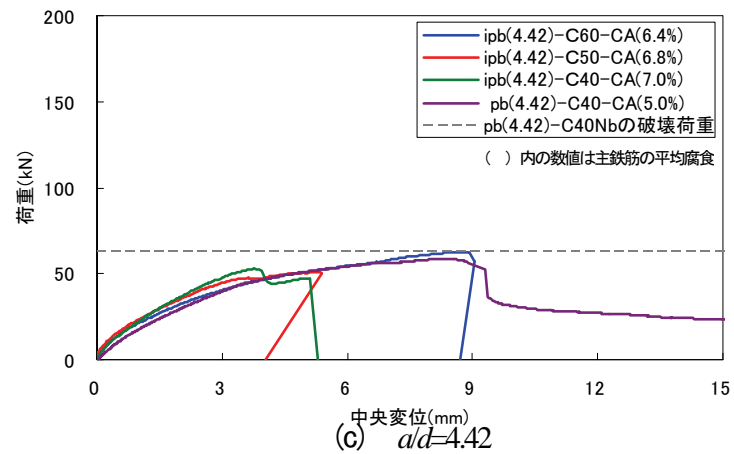

図-14 荷重と中央変位（ipbシリーズ）

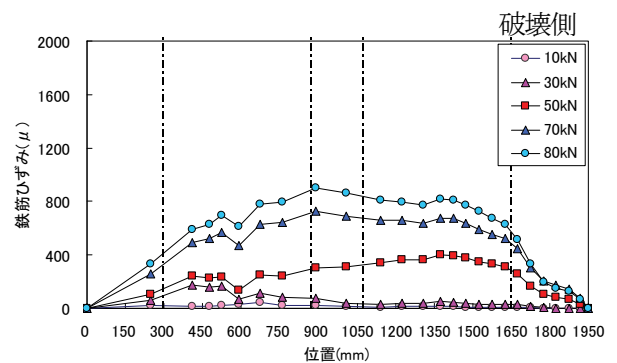

(a) $\operatorname{ipb}(2.40)-C 60-C A$

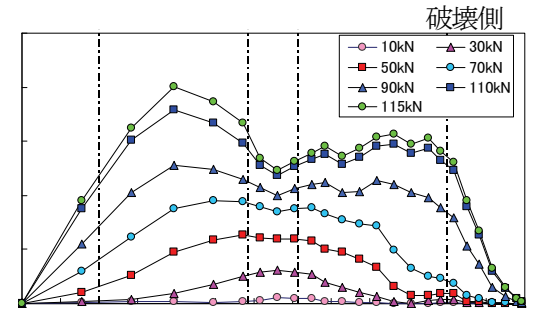

(b) $\operatorname{ipb(3.19)-C60-CA~}$

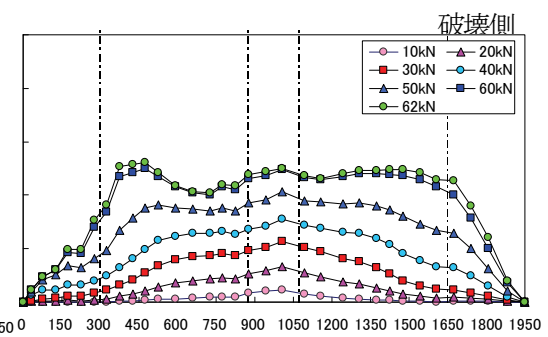

(c) $\quad \operatorname{ipb}(4.42)-C 60-C A$

図ー15 鉄筋ひずみ分布 (ipbシリーズ かぶり厚 60mm)

定で，同腐食量時点での表面ひび割れ幅はかぶりに比例 して大きくなると指摘している ${ }^{15}$. 本研究においては, いずれの試験体も主鉄筋の腐食率は同程度であることか ら，この両者の影響により，かぶり厚と腐食ひび割れ面 積の関係に相関が認めらなかったものと考えられる.

\section{b) 載荷試験結果}

ipbシリーズ試験体の破壊ひび割れ性状を図－11〜13に 示す．試験体ipb(4.42)-C40-CAを除く試験体は，主鉄筋端 部の引き込みによる付着割裂破壊であった.

図ー14にipbシリーズ試験体の荷重と中央変位の関係
を示す．同図には比較のため，不完全定着試験体と主鉄 筋の平均腐食率が近いpbシリーズ試験体の結果も示した.

まず， $a / d=2.40$ の場合では，ipbシリーズ試験体の耐力 はpbシリーズ試験体に比べて大幅な低下を示し，かぶり 厚が大きいほど，耐力が低下する傾向にあった。

a/d=3.19の場合では，かぶり厚が60mmのpb(3.19)-C60CAは，pbシリーズ試験体の耐力を若干上回り，その他 の試験体では，pbシリーズ試験体に比べて耐力は低下し た.また， $a / d=2.40$ の場合とは異なり，かぶり厚が小さ いほど耐力は減少する傾向を示した。 
a/d=4.42の場合では，耐力はかぶり厚によらず，ほぼ 同じであるが，破壊時におけるたおみ量はかぶり厚の増 加に従い増加する傾向を示した.

図ー15に一例としてかぶり厚が $60 \mathrm{~mm}$ である試験体の 各荷重レベル時における主鉄筋のひずみ分布を示す。い ずれの試験体においても，破壊側のスパンでは，ひずみ はほぼ一様な分布を示すとともに定着領域まで荷重が伝 達されたことが分かる. また, pbシリーズと同様, 定着 領域まで荷重伝達がなされた以降も，荷重は増加してい ることから，せん断力に対する抵抗機構が梁機構からア 一チ機構へと移行したものと考えられる.

ipb シリーズ試験体の耐力が pb シリーズ試験体に比べ て減少する傾向を示したことは，鉄筋腐食がはり全長に わたり生じていることから，定着領域まで荷重伝達がな されると，主鉄筋の定着が不十分であることにより鉄筋 の引き込みが生じ，破壊に至ったためであると考えられ る. すなわち, ipb シリーズ試験体の耐力の差異は主鉄 筋の定着劣化の程度の違いによると考えられる．各試験 体の主鉄筋の腐食率の差異は $2 \%$ 程度であることを鑑み れば，腐食による断面減少の違いが定着劣化の程度に及 ぼす影響は小さく，定着劣化の程度は腐食ひび割れ性状 が主として影響を及ぼしたと判断される.

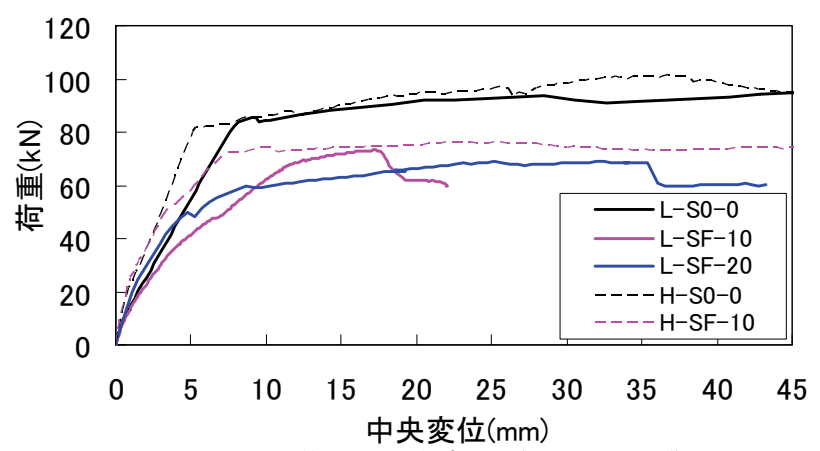

図-16 荷重と中央変位（SFシリーズ）

\section{4. 主鉄筋の付着伝達機構と曲げ断耐荷性状}

\section{（1）完全定着試験体}

図ー16に SF シリーズ試験体の荷重と中央変位の関係 を示す．同図には比較のため，鉄筋が非腐食である LS0-0およびH-S0-0の結果も併せて示した.

いずれの SF シリーズ腐食試験体も鉄筋が健全な試験 体に比べて耐力は低下した，腐食試験体の曲げ岡性は荷 重の増加とともに, 徐々に低下する傾向が確認された.

L-SF-20およびH-SF-10においては，延性的な破壊性状を 示したが，L-SF-10 は，たわみが約 $21 \mathrm{~mm}$ の時点で，は りは破壊に至り，前述した試験体に比べて脆性的な破壊 を示した.

図ー17 SF シリーズ試験体の終局時における破壊ひ び割れ性状を示す．いずれの試験体においても，鉄筋軸 に沿って付着割裂ひび割れが発生している，L-SF-20 お よび H-SF-10 においては，最終的には，等曲げ区間にお いて圧壊が生じており，破壊モードは曲げ弓張破壊であ ると判断される.

図ー17 (a)に示す L-SF-10 は，付着割裂ひび割れが進展 した後，支点上縁のコンクリートに曲げひび割れが発生 した．最終的にこのひび割れと付着割裂ひび割れが連結 したことにより定着上縁破壊を生じた。また，L-SF-10 においては，付着割裂ひび割れが鉄筋位置より上方に発 生した. これは，側面方向への腐食ひび割れが鉄筋軸よ り斜め上方に向って進展したためであると考えられる.

図－17 には各試験体の主鉄筋の平均腐食率分布およ び各荷重レベル時における主鉄筋のひずみ分布を示して いる. なお， L-SF-10においては，2100mm 側のスパンの ひずみゲージが破損したため，データが存在しない.ま た，各ひずみ分布には実線で断面諸元が同じ非腐食試験

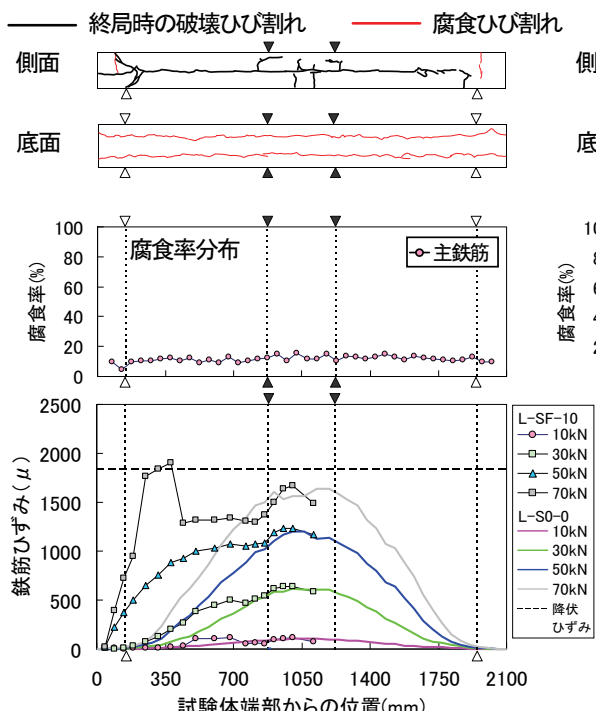

(a) 試験体 L-SF-10
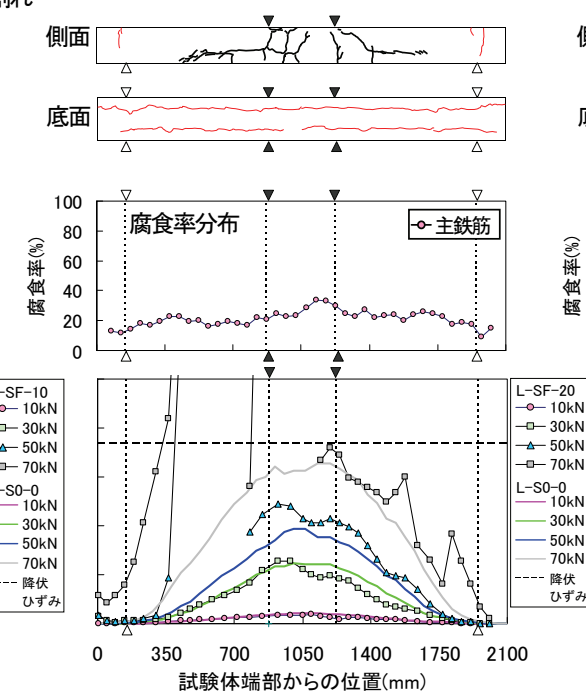

(b) 試験体 L-SF-20
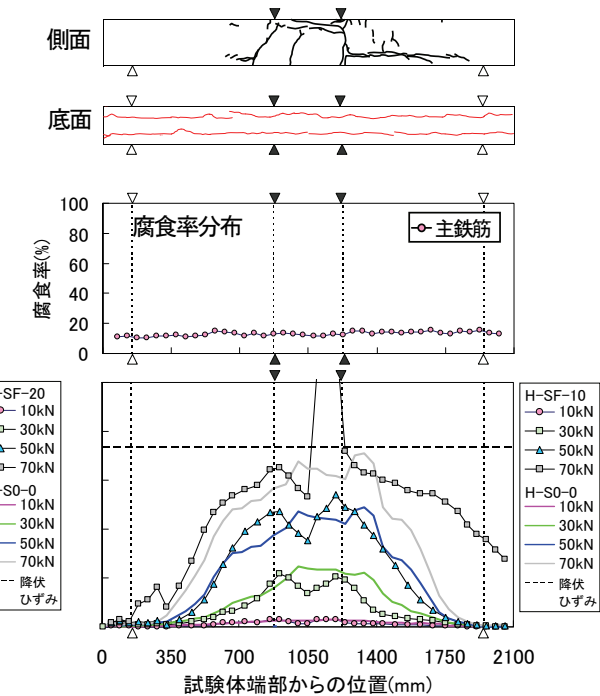

(c) 試験体 H-SF-10

図-17 載荷試験結果（SFシリーズ） 
体の結果(L-S0-0およびH-S0-0)も併せて示した.

まず，曲げ引張破壊を生じた L-SF-20 および H-SF-10 のひずみ分布は，荷重が $30 \mathrm{kN}$ 時までは放物型のひずみ 分布性状を示しており，定着領域近傍ではひずみはほと んど生じていない. また, 非腐食試験体のひずみ分布と 有意な差は認められない. 荷重が $50 \mathrm{kN}$ 時では，L-SF-20 は，斜めひび割れ先端が主鉄筋に到達した位置 (650mm) において，ひずみが局所的に大きく発生した。 荷重が 70kN 時においては，L-SF-20 および H-SF-10 とも に，非腐食試験体に比べて全体的にひずみが大きく発生 した. さらに L-SF-20 においては，0mm 側，H-SF-10 で は，2100mm 側の定着領域において比較的大きなひずみ が発生しており，端部まで荷重が伝達されたことが確認 される.また，前者は試験体端部から 650 mm 付近，後 者は等曲げ区間において鉄筋が降伏しており，両試験体 が延性的な破壊性状を示したことと整合する.

一方，定着上縁破壊を生じた L-SF-10 においては，荷 重が 30kN の時点において，0mm 側スパンのひずみ勾配 が緩やかであり，荷重が $50 \mathrm{kN}$ の時点では，支点部で約

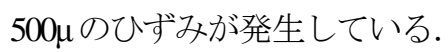

いずれの SF シリーズにおいても, 荷重レベルは異な るものの，定着領域まで荷重伝達がなされたわけである が，L-SF-10 においては，比較的低い荷重レベルの段階 から端部まで荷重伝達がなされた。このことは，L-SF20 および H-SF-10のかぶりコンクリートの平均腐食ひび 割れ幅が $0.50 \mathrm{~mm}$ および $0.15 \mathrm{~mm}$ であることに対して, $1.10 \mathrm{~mm}$ であったことを鑑みれば，かぶりコンクリート の劣化が著しく，早期にスパン内の付着が損失したと考 えられる. 寸なわち，荷重が比較的小さい段階から，支 点内での主鉄筋とコンクリートの相対ずれが大きく，前 述した定着上縁破壊メカニズムが，比較的低い荷重レべ ルから生じたことにより，早期に定着上縁破壊に至った と考えられる.

\section{（2）不完全定着試験体}

\section{a）主鉄筋のみを有する場合}

図ー18に S0シリーズ試験体の荷重と中央変位の関係 を示す. 同図には比較のため SF シリーズ試験体の結果 も併せて示した．鉄筋が健全な状態では，L，H シリー ズともに主鉄筋は降伏し，図－19(a)に破壊ひび割れ性 状を示すように曲げ引張破壊を生じた.

次に，耐力に及ぼす鉄筋腐食の影響であるが，まず， L-S0 シリーズ腐食試験体では，非腐食試験体 L-S0-0 の 耐力は健全時の約 56\%，平均腐食率が 20\%時の耐力は健 全時の約 36\%であった．また，主鉄筋の平均腐食率がほ ぼ同じである SF シリーズ試験体と比較しても，耐力は 大幅に低下していることが確認される.

Lシリーズ腐食試験体の破壊ひび割れ性状は，図－19

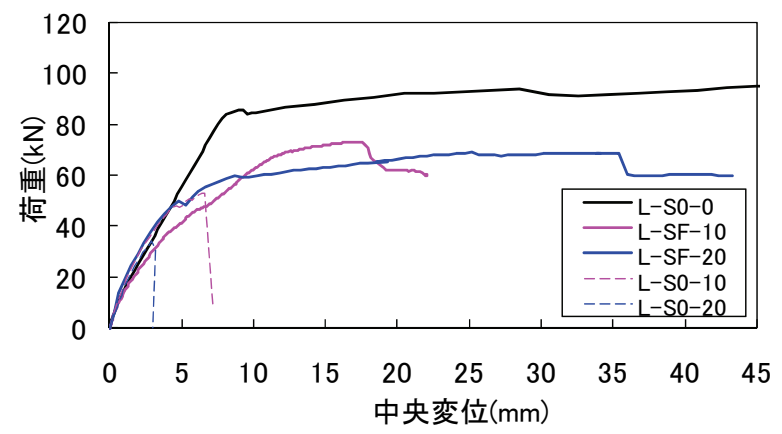

(a) L-SOシリーズ

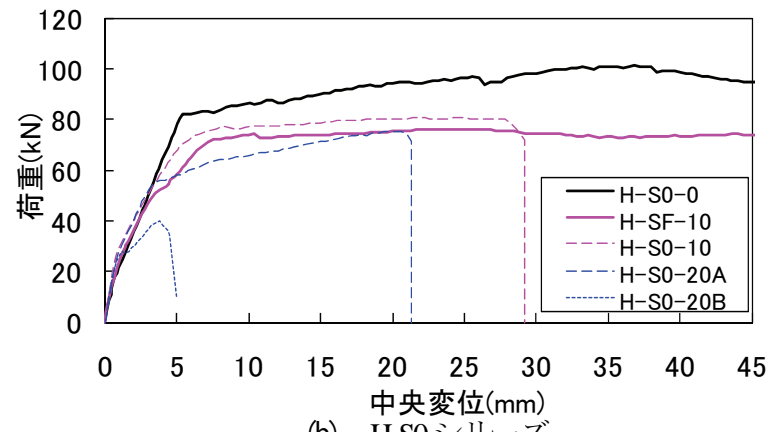

(b) H-SO シリーズ

図-18 荷重と中央変位（S0シリーズ）

(b)および(c)に示すように斜めひび割れが載荷点近傍に 発生し，付着割裂ひび割れへと進展することにより，破 壊に至った.

図一18(b)に示す H-SO シリーズ腐食試験体の荷重と中 央変位については，H-S0-10 および H-S0-20A では，鉄筋 腐食に伴う而力の低下割合は L シリーズ腐食試験体に 比べて小さく，破壊も延性的な挙動を示した.

これに対して，H-S0-20B では H-S0-0 に比べて耐力は 大幅な低下を示すとともに，極めて脆性的な破壊性状を 示した. 図ー19 に示す $\mathrm{H}$ シリーズ試験体の破壊ひび割 れ性状から，H-S0-10 および H-S0-20A では，主鉄筋に沿 ったひび割れが支点近傍，或いは支点を越えて発生して おり，L-S0 シリーズと同じく，鉄筋腐食に伴い破壊モ 一ドが曲げから付着割裂破壊へと移行したことが確認さ れる. H-S0-20B に関しては，荷重が約 40kN の時点で急 激な低下を示したが，H-S0-10 および H-SO-20A とは異な り，主鉄筋に沿ったひび割れの発生は認められない.ま た，試験終了後に鉄筋をはつり出したが，鉄筋破断は生 じていなかった．同試験体の破壊要因は後述する.

図ー19に L-S0 シリーズ試験体および H-S0 シリーズ試 験体の鉄筋のひずみ分布を示した。まず，図ー19(a)に 示す鉄筋が非腐食である試験体 L-SO-0 および試験体 HS0-0 のひずみは上に凸の放物的な分布性状を示し，荷重 が約 $90 \mathrm{kN}$ の時点では，両試験体ともに等曲げ区間の鉄 筋が降伏した．また，支点間において付着が十分に確保 されたことから，主鉄筋の定着領域近傍では，ひずみは ほとんど生じていない.

一方，腐食試験体に関しては，荷重の増加に伴ってせ 


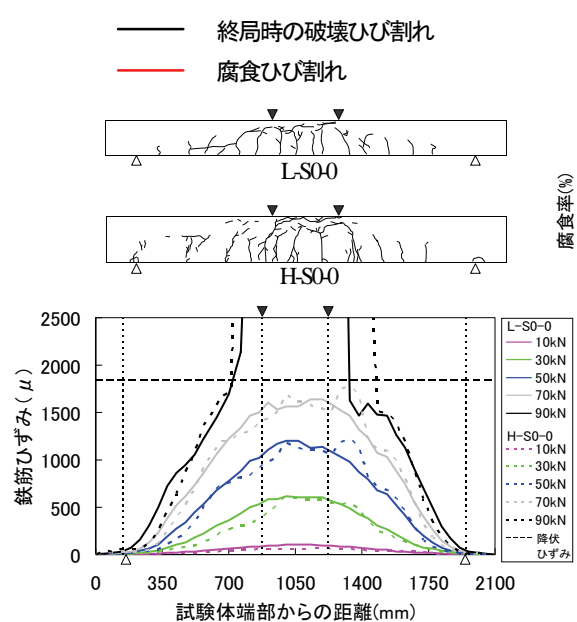

（a）試験体 $\mathrm{L}-\mathrm{S} 0-0 \cdot \mathrm{H}-\mathrm{S} 0-0$ (非腐食)
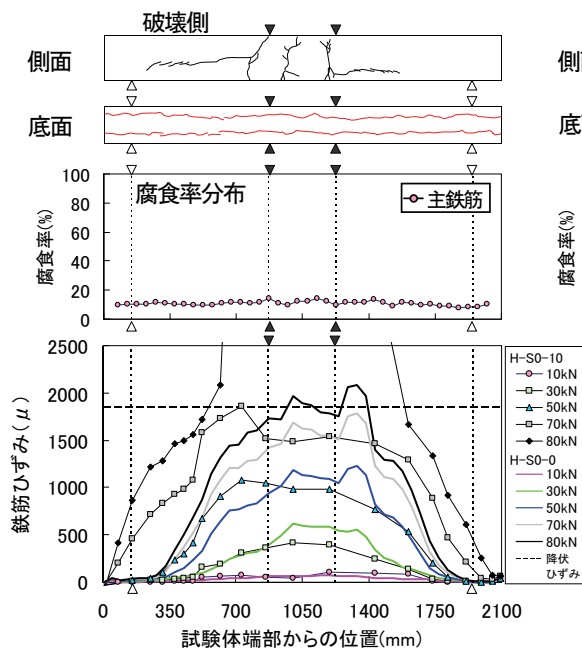

(d) 試験体 H-S0-10
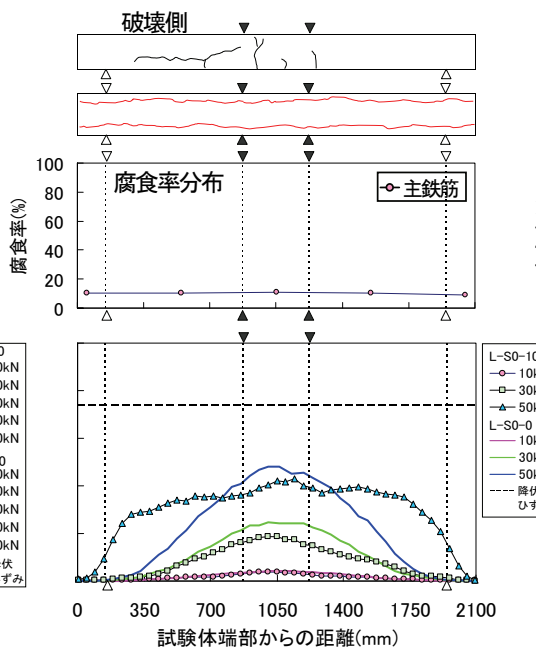

(b) 試験体 L-S0-10
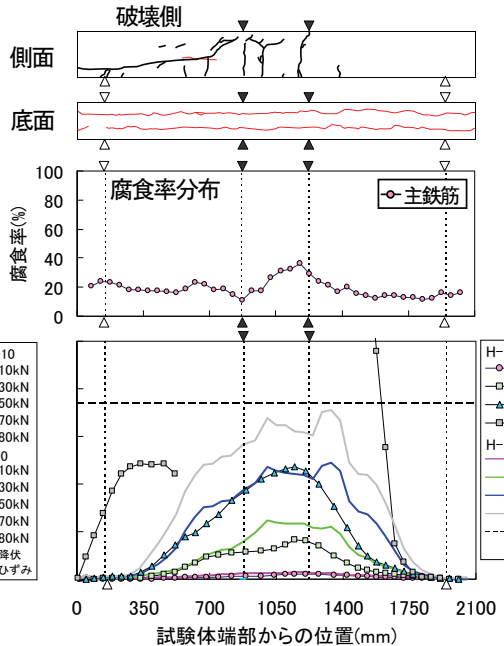

(e) 試験体 H-SO-20A

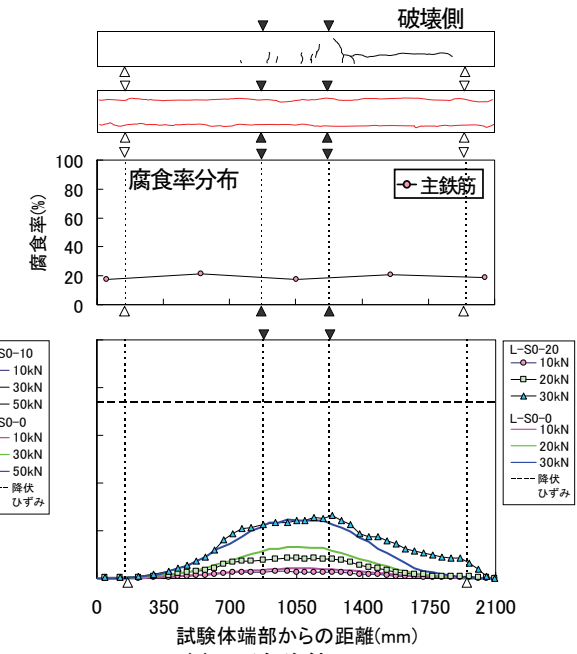

(c) 試験体 L-S0-20

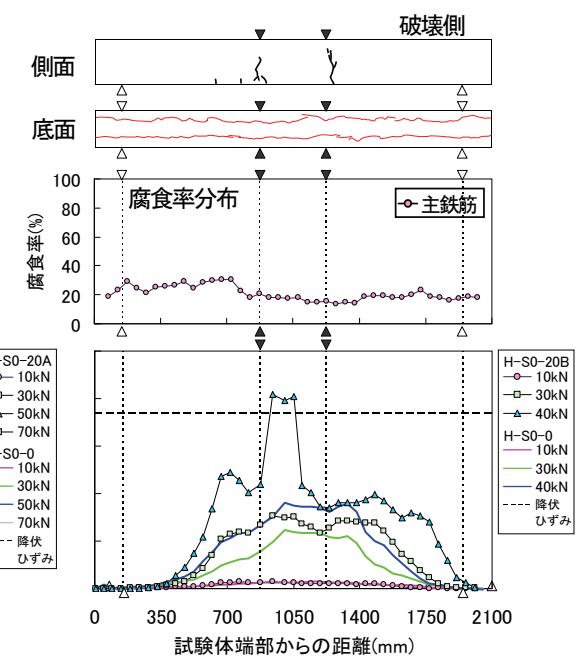

(f) 試験体 H-S0-20B

図-19 載荷試験結果(S0シリーズ)

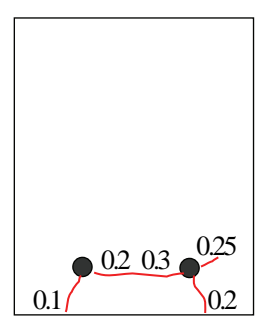

(a) 試験体 H-SO-20A

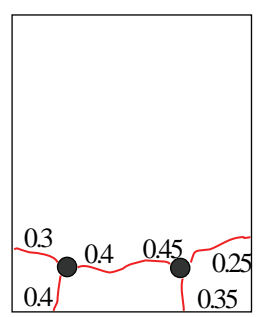

(b) 試験体 H-SO-20B

ん断スパンのひずみ勾配が緩やかになるとともに，定着 領域までひずみが発生しており，鉄筋腐食に伴う付着劣 化により，主鉄筋定着領域まで比較的大きな荷重伝達が なされた，定着領域まで荷重伝達がなされると，定着不 良を生じていることから，主鉄筋の引き込みにより，は りは，破壊に至っており，定着性能が而荷性状に極めて 大きな影響を及ぼしている.

H-S0-20B においては，等曲げ区間において，鉄筋が 降伏しているが，同時にスパン右側でひずみ勾配が緩や かになっている．前述したように，同試験体は鉄筋破断 は生じていなかったことから，破壊は他の S0 シリーズ

腐食試験体と同様，主鉄筋の引き込みに起因すると考え られる. なお，付着割裂ひび割れは発生していないこと から，付着破壊と称することとする.

鉄筋軸に沿った破壊ひび割れが発生しなかったことは, 著しい付着劣化により，鉄筋からコンクリートへの応力 伝達がなされず，割裂力が小さかったためであると考え られる。 また，H-S0-20A および H-S0-20B の耐力が大き く異なったことは，両試験体の主鉄筋の平均腐食率がほ ぼ同じであることから，かぶり面の腐食ひび割れ性状の 違いが主たる要因であると考えられる.

図－20 に両試験体の端面の腐食ひび割れ性状を示す ように，耐力の低下が比較的小さい H-S0-20A では，鉄 筋軸水平方向に腐食ひび割れ進展は少ない.

一方，H-S0-20B では，鉄筋軸水平方向に腐食ひび割 れは側表面近傍まで進展しており，その幅も大きい. か ぶりコンクリートの腐食ひび割れ性状は，付着性能の低 下に大きな影響を及ぼすことから，H-SO-20B では定着 領域まで荷重伝達がなされると, 定着領域でその荷重を 負担出来ずに，主鉄筋の引き込みが生じたと考えられる. 


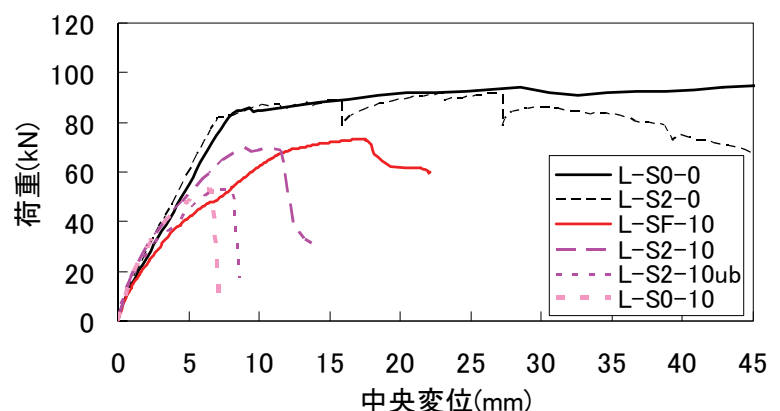

(a) 腐食率約 $10 \%$

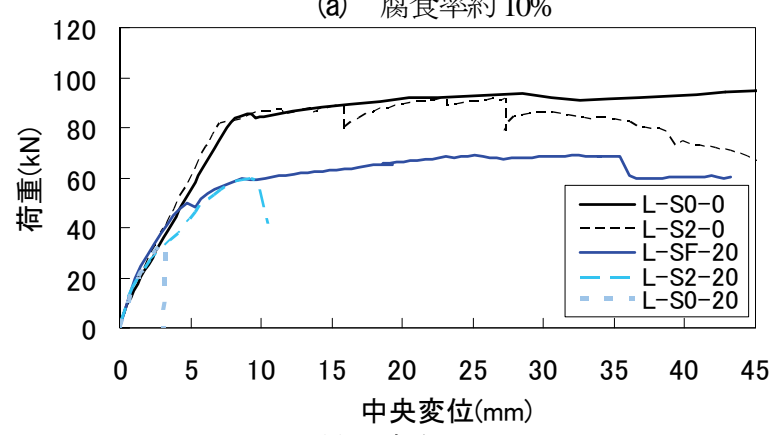

(b) 腐食率約 20\%

図-21荷重と中央変位（L-SA シリーズ）
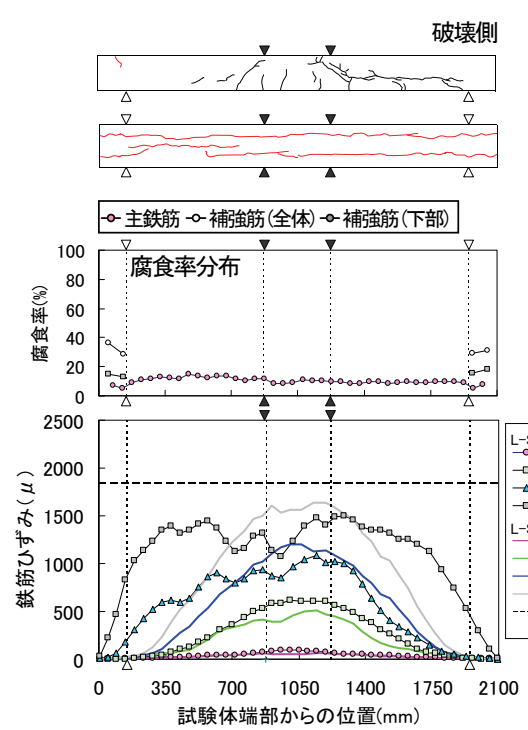

(a) 試験体 L-S2-10

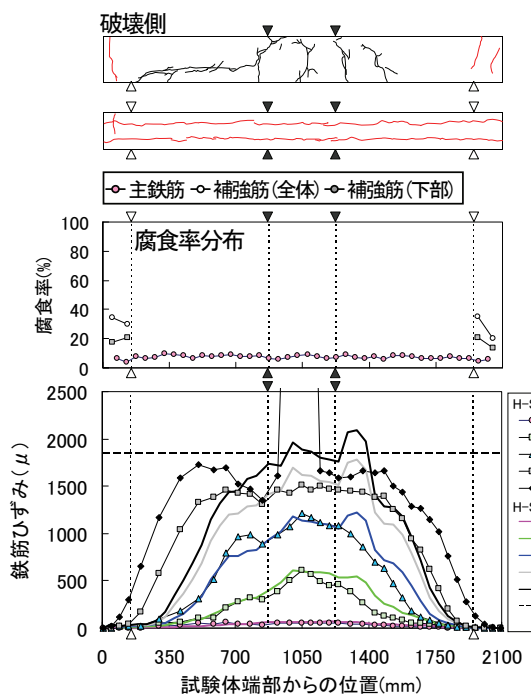

(d) 試験体 H-S2-10
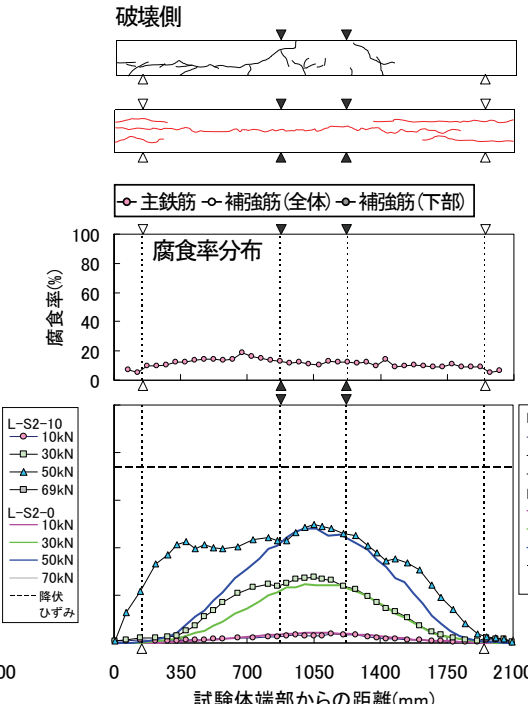

(b) 試験体 L-S2-10ub
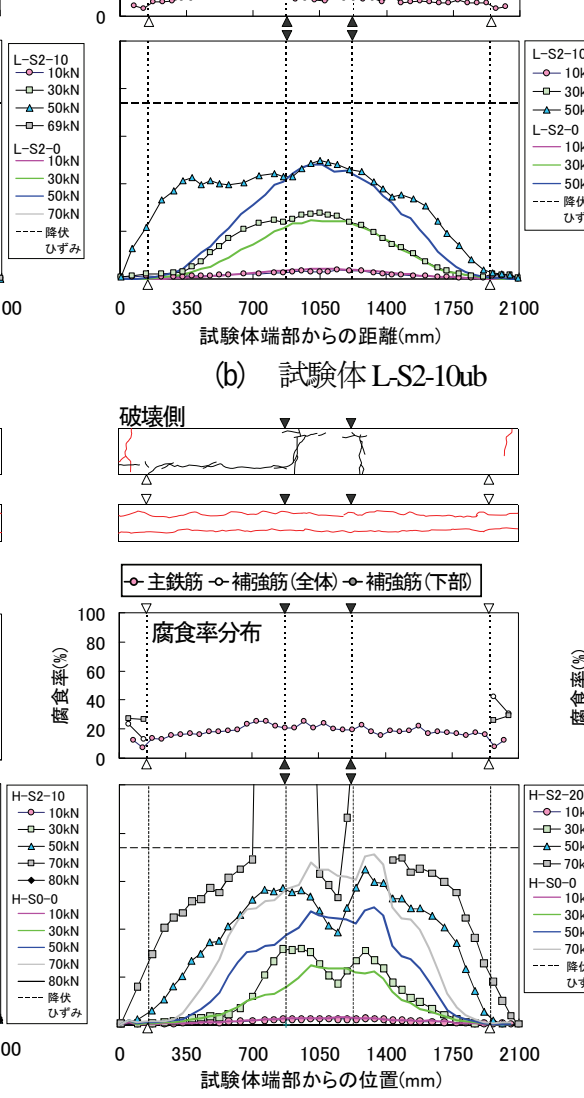

(e) 試験体 H-S2-20

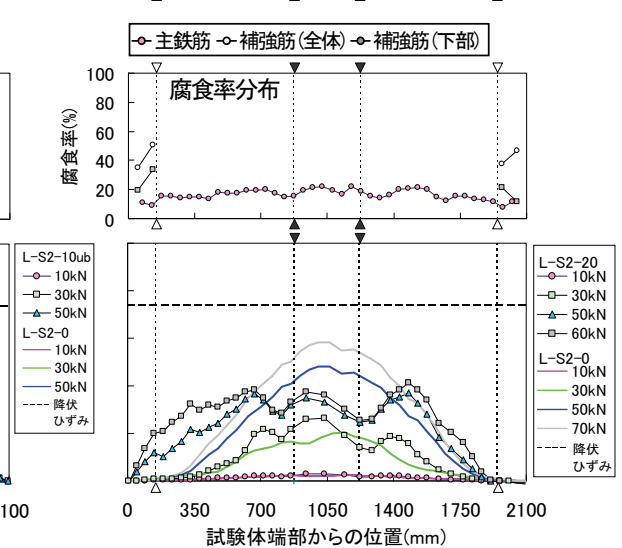

(c) 試験体 L-S2-20

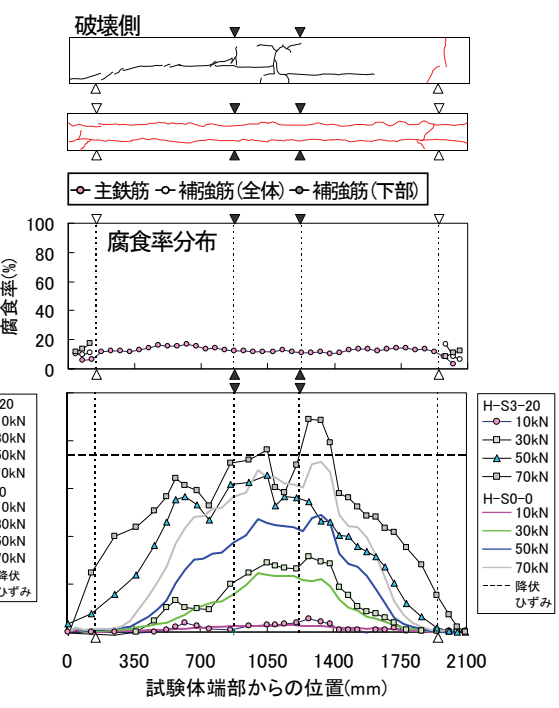

(f) 試験体 H-S3-20

図一23 載荷試験結果（SA シリーズ） 


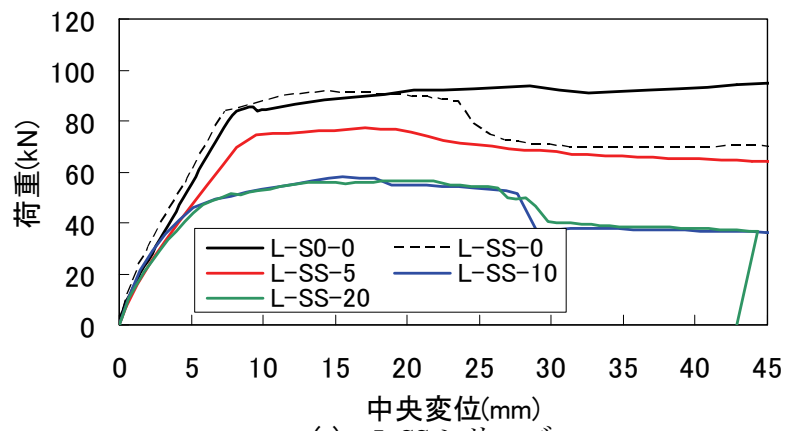

(a) L-SS シリーズ

図一24 荷重と中央変位（SS シリーズ）

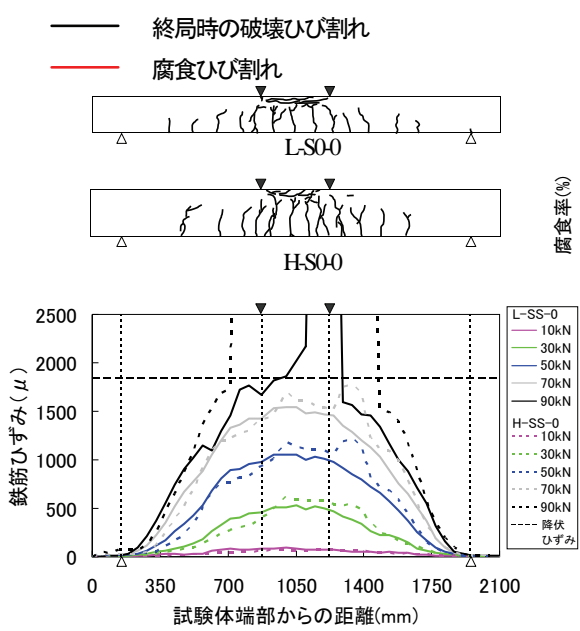

(a) 試験体 L-SS-0, H-SS-0

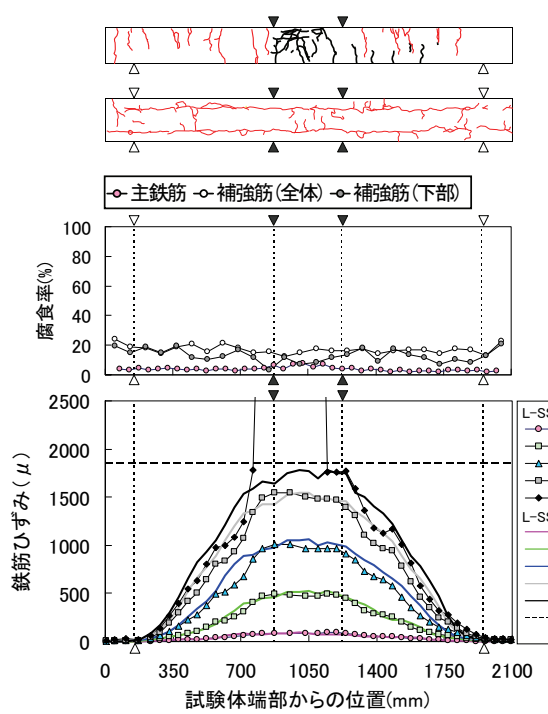

(b) 試験体 L-SS-5
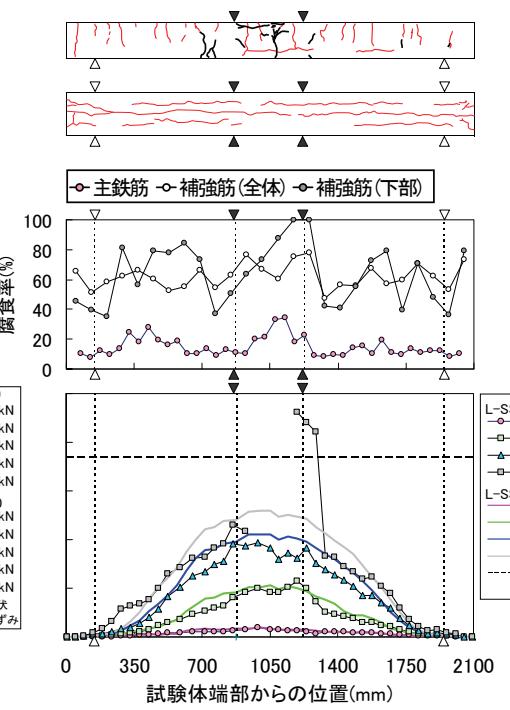

（c） 試験体 L-SS-10
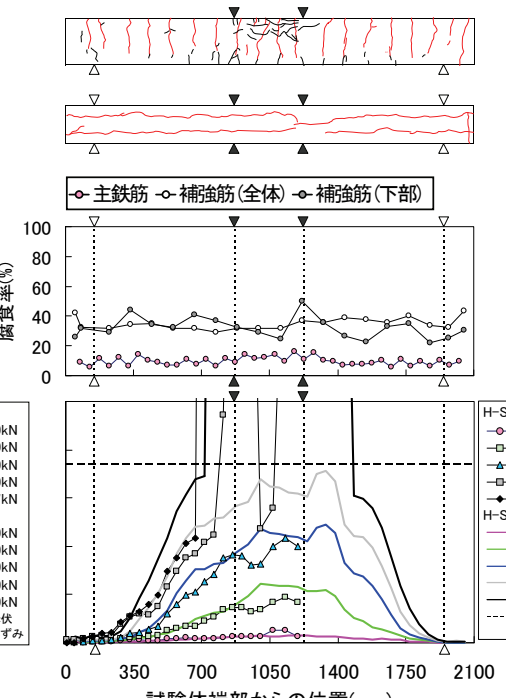

験体端部からの位置(mm)

(d) 試験体 H-SS-10
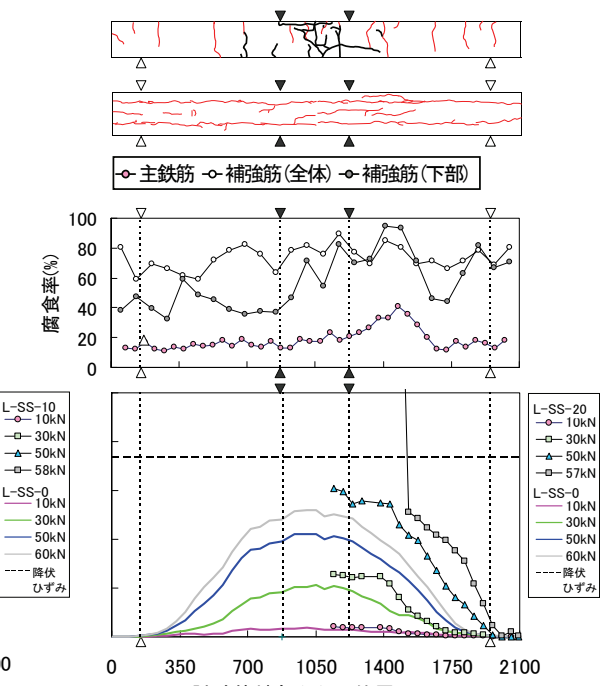

試験体端部からの位置 $(\mathrm{mm})$

(e) 試験体 L-SS-20
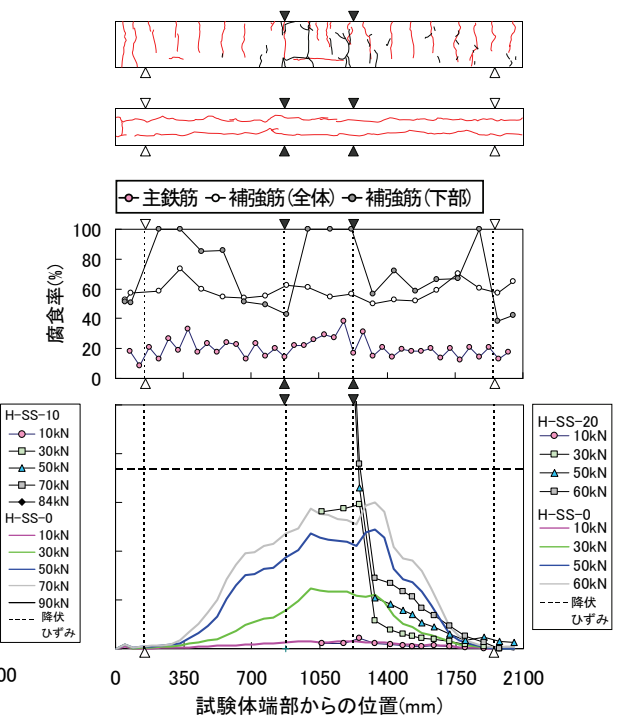

(f) 試験体 H-SS-20

図ー25 載荷試験結果（SS シリーズ）

\section{b）定着筋を有する場合}

図ー21 および図-22 に SA シリーズ試験体の荷重と 中央変位の関係を示す. 同図には比較のため S0 シリー ズおよび SF シリーズ試験体の結果も併せて示している. まず，L-SA シリーズにおいて，鉄筋が健全である LS2-0 は，スパン内の付着が十分であることから， L-S0-0 の荷重変位関係と明確な差異は生じていない。
一方，鉄筋腐食を生じた場合では，定着筋を有する試 験体（L-SA シリーズ）の耐力低下は定着筋を有しない 試験体（L-S0 シリーズ）に比べて抑制された。変形性 能に関しては，S0 シリーズ腐食試験体と比較して，破 壊時のたわみ量は増加しているが脆性的な破壊であり, 図－23 に示す L-SA シリーズ試験体の破壊ひび割れ性状 から付着割裂破壊を生じていると判断される. 
定着筋をアンボンドとした L-S2-10ub では, L-S0 シリ 一ズ腐食試験体と同様，耐力が大幅に低下寸るとともに 極めて脆性的な破壊性状を示しており，定着筋の付着劣 化が而荷性状に非常に大きな影響を及ぼすことを示唆し ている．既往の研究において，主鉄筋下側領域において せん断補強筋の付着劣化が生じると, せん断而荷性能が 低下寸ることが報告されている ${ }^{14,16) . ~}$ 定着筋に関しても， 主鉄筋の付着劣化により定着部まで荷重が伝達される場 合には，定着筋の付着性能が而荷性状に大きな影響を及 ぼすと考えられる.

H-SA シリーズに関しては, 図ー22(a)に示寸 H-S2-10 と H-S0-10 の荷重と中央変位を比較すると, 破壊時の中 央変位は試験体 H-S2-10 の方が約 10mm 大きいが，残存 耐力に差異はない．これは，図一23(d)に鉄筋ひずみ分 布を示すように，定着破壊を生じる前に等曲げ区間にお いて主鉄筋が降伏に至ったためである。また, 図一 22(b)に示すように，主鉄筋の平均腐食率が約 20\%であ る H-S2-20 と H-S0-20B を比較すると, H-S2-20 は定着筋 を配筋したことで，残存耐力の低下が大幅に抑制される とともに，変形性能も向上している．また，定着筋量の 多い H-S3-20 および H-S4-20 においても耐力の低下は大 幅に抑制されているが，試験体 H-S2-20 とは明確な差異 は生じておらず，本実験の範囲内では定着筋量によらず, 耐力はほぼ同様であった。 これら腐食試験体における定 着筋の腐食率は表一1 に示寸ように 20\%程度であり, 目 視により破断が生じていないことも確認されている.こ のことはすなわち, 定着筋による主鉄筋の拘束効果は期 待できるものの, その効果を発揮する量には上限值があ るものと考えられる.

図一24にSS シリーズ試験体の荷重と中央変位の関係 を示す．いずれのシリーズにおいても，腐食試験体は非 腐食試験体に比べて耐力は低下しているものの, 延性的 な破壞性状を示している，L-SS シリーズおよび H-SS シ リーズ試験体の破壊ひび割れ性状を図ー25に示寸が, 腐食試験体は非腐食時に比べてひび割れ分散性能は低下 しているものの，主鉄筋のみを有する試験体と異なり， 斜めひび割れや鉄筋軸に沿った水平ひび割れは発生して いない.

図一25に SS シリーズ試験体のひずみ分布性状を示す。 両シリーズともに鉄筋腐食を生じた試験体のひず夕分布 は上に凸の放物線的な性状を示し, 荷重の増加に伴って 等曲げ区間近傍の主鉄筋が降伏している．また，L-SS20 を除き, 主鉄筋の定着領域において鉄筋ひずみは, ほとんど発生しておらず，せん断補強筋の存在によって 定着領域まで荷重伝達がなされていない。

L-SS-20 においては，表一1 に示したようにせん断補 強筋の腐食率が大きい. はつり出し後の目視観察の結果, 複数の補強筋に破断が生じていたことから, せん断補強

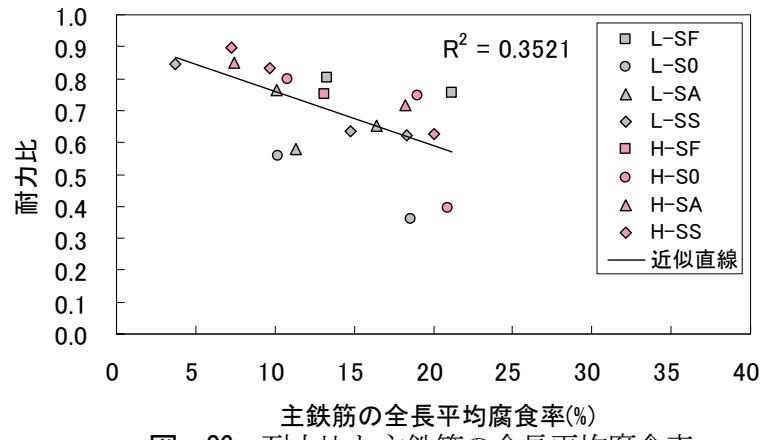

図一26 耐力比と主鉄筋の全長平均腐食率

筋による主鉄筋の拘束効果が他の試験体に比べて低下し たため, 定着領域まで荷重が伝達したと考えられる.

せん断補強笳は主鉄筋に比べて鉄筋径が小さく, かぶ り厚も小さいため, 鉄筋腐食が著しく進行する. せん断 補強筋の腐食が過度に進行した領域が広範囲にわたると, 荷重が定着領域まで伝達され，S0シリーズ或いは SA シ リーズのように，定着領域まで荷重が伝達される，この ような状態では，定着性能が残存耐力に極めて大きな影 響を及ぼすことになる.

\section{5. 鉄筋腐食を生じたRCはりの耐荷性状に及ぼす 主鉄筋の腐食と耐荷力}

\section{(1) 曲げ耐力の定量的評価}

図一26に曲げ破壊先行型試験体における主鉄筋の平 均腐食率と耐力の関係を示寸. 各試験体の耐力は断面諸 元が同じ非腐食試験体の耐力で除することにより正規化 した．なお，L-SF シリーズは L-S0-0，H-SF シリーズお よび H-S2シリーズは H-S0-0 の耐力で正規化した.

全体的な傾向としては，主鉄筋腐食率の増加にしたが い耐力は低下する傾向にあるが，腐食率に応じた耐力比 の低下率は断面によって異なるとともに, 断面が同じで あっても, 定着筋やせん断補強筋の有無によって耐力の 低下量は大きく異なっている.このことは，鉄筋腐食に 伴う耐力低下が主鉄筋の断面減少に加えて, 腐食ひび割 れ性状, 主鉄筋の付着劣化性状, 主鉄筋の腐食の不均一 性など鉄筋腐食に起因した種々の材料劣化によって引き 起こされることを示している.ささらに，これら材料劣化 が而荷性状に及ぼす影響度は断面諸元によっても異なる とともに，せん断補強笳や定着筋といった補強筋の腐食 状況によっても異なる. 特に, 本研究のように定着不良 が生じると，曲げ破壊を生じる以前に付着割裂破壊を生 じ，耐力が大幅に低下寸る場合がある，すなわち，設計 時では曲け破壞が先行する断面諸元であっても，鉄筋腐 食に伴い, 現有の曲げ而荷性能やせん断而荷性能が変化 し，破壊モード自体が設計時と異なる場合もある。した がって, 図一26に示したように, 単に主鉄筋の平均腐 
食率のみで耐力評価を行うことは困難であり, 破壊モー ド毎に耐力に及ぼす影響評価を行う必要があるものと考 えられる。

図一27 は，主鉄筋が降伏し曲げ破壊を生じた試験体 を対象として，耐力比と主鉄筋の等曲げ区間の平均腐食 率との関係を示したものである. 図中の実線は，鉄筋の 断面減少および見掛けの降伏応力の低下を考慮し，曲げ 理論から算出した耐力比である ${ }^{14}$. また，同図には既往 の実験結果も併せて示している ${ }^{14,17)}$. なお, 文献 14),

17）の試験体の形状寸法は L シリーズと同様である.

図一27に示寸ように, 文献 17)の結果を除き, 腐食試 験体の耐力比は，断面によらず材料劣化を考慮して曲げ 理論に基づき算出した耐力比と比較的近い值を示した. このことは，曲げ耐力に関しては，主鉄筋の腐食程度が 支配的な要因であることを示している. しかしながら， 文献 17)およびその他の幾つかの試験体は，理論值に比 べて耐力比は小さい值を示した. 特に文献 17)の耐力比 は，算定値に比べて大幅に小さい，これは，腐食の不均 一性によるものである. 文献 17においては，曲げモー メントが作用した状態で腐食促進試験を行ったことから, 曲げひび割れ発生箇所近傍で腐食が著しく進行しており その領域において局部的に破壊が進行した。 このような 場合は局所的な鉄筋の材料劣化が耐力に支配的な影響を 及ぼすと考えられる.

図一28 は耐力比と等曲げ区間内の最大腐食率との関 係を示したものであるが，文献 17)の腐食試験体を含め, 概祆安全側の評価となっている.

既往の研究において，作用モーメントの大きい等曲げ 区間やその近傍において，主鉄筋の腐食の不均一性が生 じた場合，その領域において変形が局所化し，曲け破壞 を生じることを指摘した ${ }^{14)}$. また，変形の局所化が生じ る指標としてはり全長にわたり鉄筋腐食が生じている場 合，式(1)に示す偏差率を提案し，その閾值を 0.9 とした

$$
k=\left(\alpha-\alpha_{a_{v g}}\right) / \alpha_{a_{v g}}
$$

ここで, $k:$ 偏差率， $\alpha:$ 主鉄筋の局所的な平均腐率, $\alpha_{\text {ovg }}:$ はり全長の平均腐食率である.

\section{（2）完全定着状態におけるせん断耐力の定量的評価}

鉄筋腐食を生じた RC はりのせん断耐力は，主鉄筋と コンクリートの付着応力性状の影響を大きく受ける. 支 点間の付着性能が低下寸ると，せん断而荷機構がはり機 構からア一チ機構一移行する. その場合, 主鉄筋定着の 劣化程度（定着性能）が耐力に支配的となる. 言い換え れば定着性能から現有の残存せん断耐力を推定すること が可能であると考えられる，そこで，本研究では上記観 点に立脚し，定着性能に基づく残存せん断耐力評価モデ ルの構築を試みる。

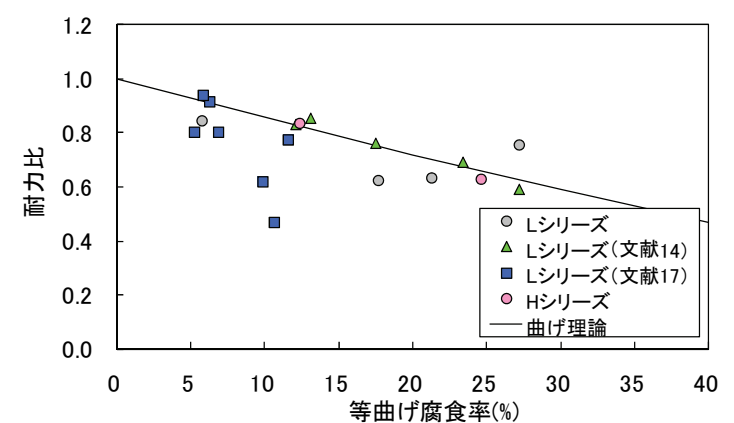

図一27 耐力比と主鉄筋の等曲げ区間平均腐率（曲げ破壊時）

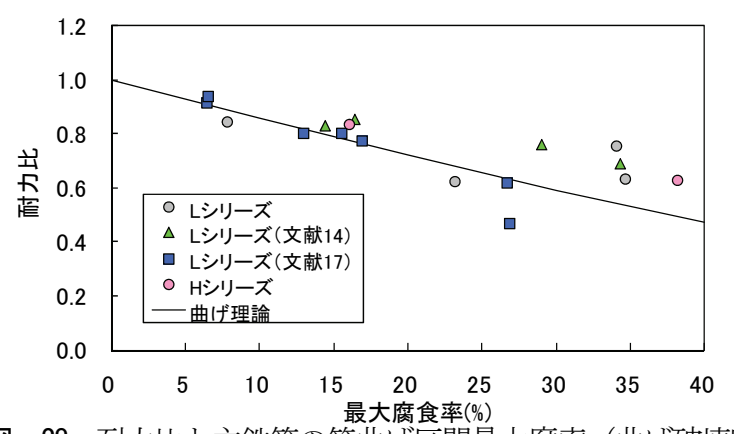

図一28 耐力比と主鉄筋の等曲げ区腐食率大䧹率（曲げ破壊時）

\section{a) 解析的検討}

前述した載荷試験結果から，定着不良時における耐力 は，定着性能に加えて a/d が影響すると考えられるため， まず，アーチ而荷性状に及ぼす a/d の影響を定量的に評 価する.

解析は，非線形解析ソフト ATENA(Ver.4.2.2)を用いた. 解析モデルを図一29 に示寸. 解析は平面応力状態を仮 定した 2 次元解析である. 解析モデルに示すように, 本 解析ではかぶりコンクリートを無視し，引張主鉄筋とコ ンクリートとの間を不連続とし，スパン内に付着が生じ ないようにした. 支点外側の領域については完全付着と した．また，載荷板の幅は 50mmであり，載荷板中央の 上縁に $0.1 \mathrm{~mm} / \mathrm{step}$ の強制変位を与えた. 解析パラメータ および解析に用いた物性值は表一4に示寸通りである.

コンクリートの圧縮側の構成側は応力ピーク点までは CEF-FIP コード 90 に従い, 応力ピーク後は応力を直線的 に低下させた. 引張側の構成側はひび割れが発生する以 前は線形弾性とし，ひび割れ発生後は Hordijk によって 提案された指数関数型のひび割れ開口則を用いた ${ }^{18)}$. ま た，ひび割れ発生後のせん断係数は Kolmar 則により低 減されるものとした ${ }^{19}$. なお, 支点上縁における負曲げ の発生による定着破壞を防止するため, 試験体端部から 400mm までの領域のコンクリートは弾性体とした.

鉄筋の応力ひずみ関係はバイリニアとし，降伏応力以 後は一定值とした.

\section{b）せん断スパン比(a/d)の影響}

いずれのケースにおいても，最大モーメント区間にお いて，はり中央部の上縁コンクリートが圧壊して破壊に 至った. 


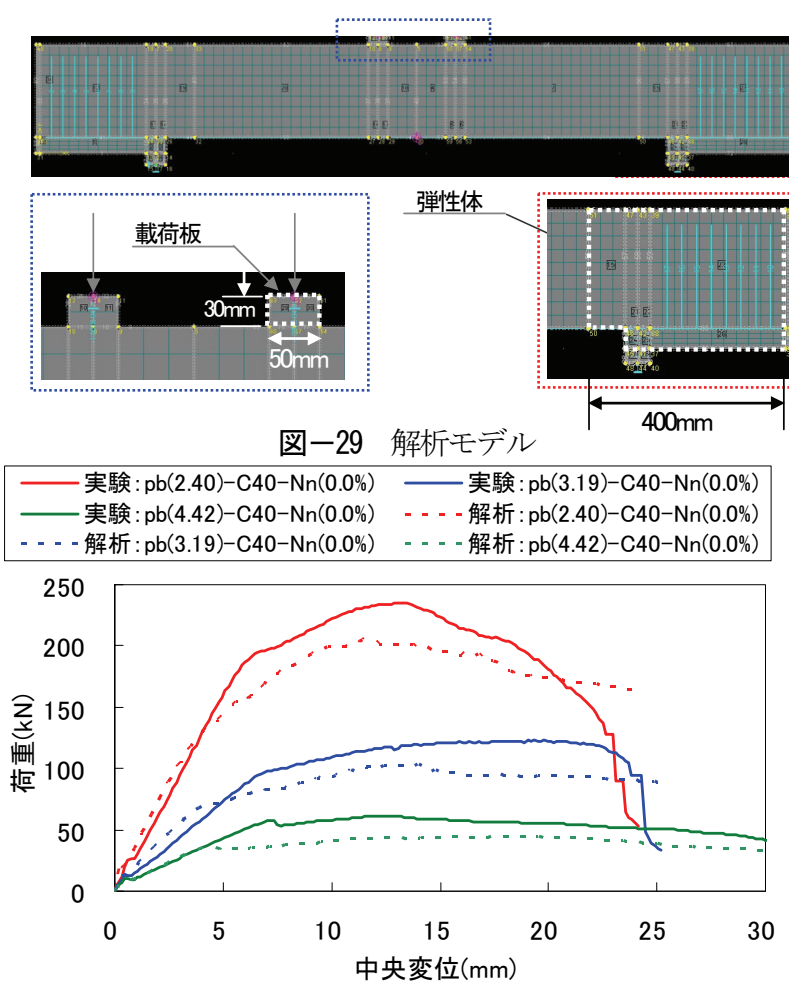

図－30 荷重と中央変位の比較（アンボンド試験体）

図ー30 にアンボンド試験体の解析結果と実験結果の 荷重と中央変位の関係を示す. 解析結果は実験結果に比 べて全体的に若干小さい值を示しているが，比較的良好 な一致を示した。

また，図一31 に $a / d=2.40, a / d=3.19, a / d=4.42$ における 終局時の最小主応力分布を示すが，いずれの試験体も載 荷点と支点を結び圧縮ストラットが形成され，アーチ機 構によって荷重が保持されていることが確認される.

図一32 に最大せん断応力と a/d の関係を示す. 最大せ ん断応力は $a / d$ の増加にしたがい, 線形的に減少する傾 向を示している. 解析結果と実験結果を比較すると, 両 者は比較的良好な一致を示した。

図一33 に斜め引張破壊時のせん断耐力 $\left(V_{c}\right)$ により基準 化したアンボンド試験体のせん断而力 $\left(V_{\text {arch }} / V_{c}\right)$ と a/d の 関係を示す.

基準化に用いた斜め引張破壊時の耐力は，実験は，構 造諸元が同じ試験体のせん断耐力とし，解析では，式 (2)に示すせん断耐力算定值とした ${ }^{20)}$.

$$
V_{c}=0.2 f_{c}^{\prime 1 / 3}\left(100 p_{t}\right)^{1 / 3}\left(\frac{10^{3}}{d}\right)^{1 / 4}\left(0.75+\frac{1.4 d}{a}\right) b_{w} d
$$

ここで, $f_{c}$ : コンクリートの圧縮強度 $\left(\mathrm{N} / \mathrm{mm}^{2}\right), p_{t}$ : 引 張鉄筋比, $d$ : 有効高さ $(\mathrm{mm}), b_{w}$ : 部材幅 $(\mathrm{mm})$ である.

図ー33 より，アンボンド試験体のせん断耐力は, ア 一千而荷機構の形成により，斜め引張破壊時の耐力と同 等かそれ以上となったが，a/d が増加するにしたがい， 耐力の増加率は減少した. 解析結果も含めて考察を行う

表一4 解析パラメータ

\begin{tabular}{|c|c|c|c|c|c|c|c|c|c|}
\hline \multicolumn{2}{|c|}{ 解析パラメータ } & 1 & 2 & 3 & 4 & 5 & 6 & 7 & 8 \\
\hline \multicolumn{2}{|r|}{$a / d$} & 1.51 & 1.98 & 2.40 & 2.74 & 3.19 & 3.83 & 4.42 & 5.75 \\
\hline \multicolumn{2}{|r|}{ 有効高さ(mm) } & 380 & 290 & 240 & 210 & 180 & 150 & 130 & 100 \\
\hline \multicolumn{2}{|c|}{ せん断スパン長 $(\mathrm{mm})$} & \multicolumn{8}{|c|}{575} \\
\hline \multirow{5}{*}{ コンクリート } & 圧縮強度 $\left(\mathrm{N} / \mathrm{mm}^{2}\right)$ & \multicolumn{8}{|c|}{24.5} \\
\hline & 弾性係数(N/mm²) & \multicolumn{8}{|c|}{25000} \\
\hline & 引張強度 $\left(\mathrm{N} / \mathrm{mm}^{2}\right)$ & \multicolumn{8}{|c|}{2.23} \\
\hline & 破壊エネルギー $(\mathrm{N} / \mathrm{m})$ & \multicolumn{8}{|c|}{55.8} \\
\hline & ポアソン比 & \multicolumn{8}{|c|}{0.2} \\
\hline \multirow{2}{*}{ 主鉄筋 } & 降伏応力 $\left(\mathrm{N} / \mathrm{mm}^{2}\right)$ & \multicolumn{8}{|c|}{685} \\
\hline & 弾性係数(N/mm²) & \multicolumn{8}{|c|}{200000} \\
\hline \multirow{2}{*}{ 定着筋 } & 降伏応力 $\left(\mathrm{N} / \mathrm{mm}^{2}\right)$ & \multicolumn{8}{|c|}{295} \\
\hline & 弾性係数 $\left(\mathrm{N} / \mathrm{mm}^{2}\right)$ & \multicolumn{8}{|c|}{200000} \\
\hline
\end{tabular}

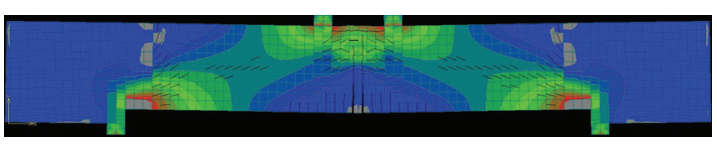

(a) $a / d=2.40$

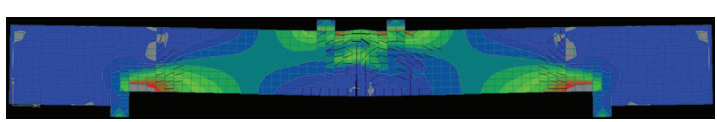

(b) $a / d=3.19$

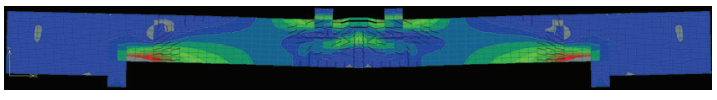

(c) $a / d=4.42$

図一31 最小主応力図

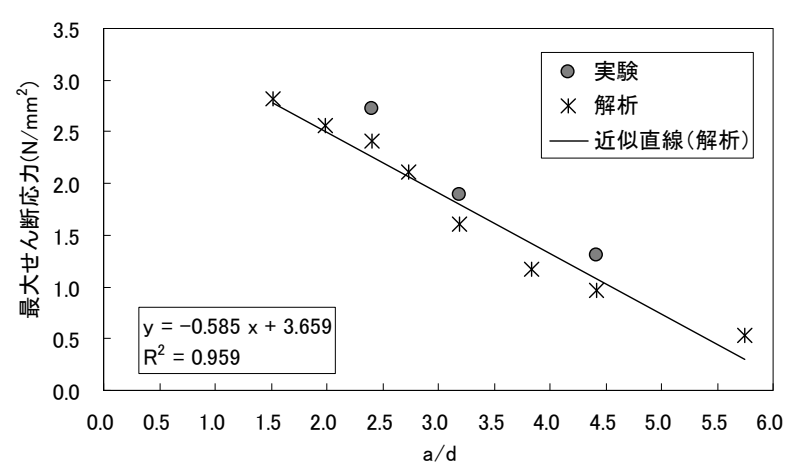

図一32 最大せん断応力と $a / d$

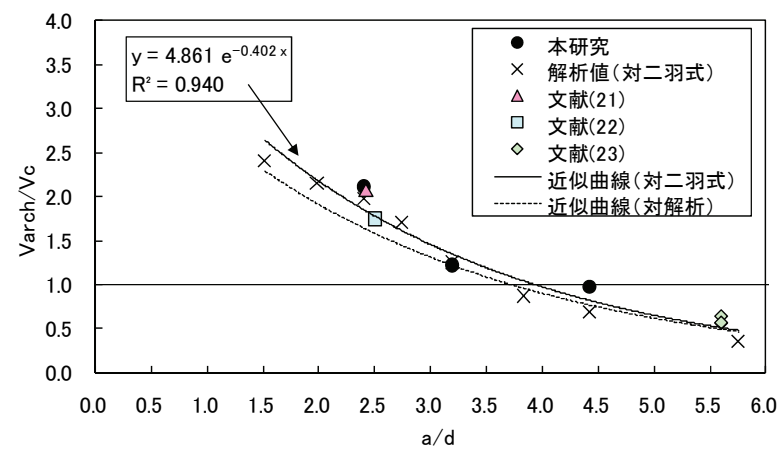

図一33 せん断耐力比と a/d

と，a/dが 3.5 を超えると，斜め引張破壊時の耐力を下回 る結果となった。これは，a/d が大きくなるにしたがい， 形成される圧縮ストラットの幅が小さくなり， $a / d=3.5$ 以 上になると, ア一チ耐荷機構による耐力増加が期待でき ないものと考えられる.

図一33 には既往の支点間をアンボンドとした RCはり の曲げ載荷試験結果を示している 21), 22, 23). 本実験結果を 含め, 解析結果と実験結果は比較的良好な一致を示して 
おり，斜め引張破壊時からの耐力の変化率に a/d の影響 は大きいと推察される.

図一33 に示す解析結果および実験結果から，回帰式 を求めれば，支点間をアンボンドしたはりのせん断耐力 は式(3)に示すようになる.

$$
V_{\text {arch }}=[4.861 \exp (-0.402 \cdot a / d)] \cdot V_{c}
$$

ここで, $V_{\text {arch }}$ : アンボンド試験体のせん断耐力, $a / d$ : せん断スパン比, $V_{c}$ : 斜め引張破壊時のせん断耐力であ る。また，図一33 には，解析結果の基準化に用いるせ 儿断耐力 $\left(V_{c}\right)$ に解析值を用いた場合の近似曲線を破線で 示しているが，二羽式で正規化した場合と大きな差異は ない.

\section{（3）定着不良時のせん断耐力評価}

\section{a) 主鉄筋の腐食率の影響評価}

図一34に鉄筋を試験体端部で固定した腐食試験体(pb シリーズ)の破壊時のせん断耐力とアンボンド試験体而 力との比(以降ア一チ耐力比と称する) と主鉄筋の腐食 率の関係を示したものである. 同図には既往の研究にお いて，主鉄筋を試験体端部で固定した腐食 RC はり(せ ん断破壊型)の載荷試験結果も併せて示している 24),25).

図一34より, 而力比と主鉄筋の腐食程度には明確な相 関性が認められず，耐力の大きさに主鉄筋の腐食に伴う 断面減少の影響は少ないものと判断される.このことは, 試験パラメータが同じ試験体 H-SO-20A および試験体 HS0-20B の耐力が大きく相違したことにも関連する。す なわち，鉄筋の腐食率が同程度であっても，かぶりコン クリートの腐食ひび割れ性状に起因する付着劣化程度の 違いによって異なる耐荷性状を示すこととなる.

図－35に定着不良試験体の最大せん断応力と定着性 能の関係を示す。ここで，定着性能とは破壊を生じたス パンの定着領域（試験体端部から 400mm）の最大荷重 時の平均付着応力である。また，図中にはアンボンド試 験体の結果を示すとともに, pb シリーズ腐食試験体の 結果も示している. $\mathrm{Pb}$ シリーズ腐食試験体は定着上縁 破壊或いは定着上縁・圧壊であるが，その時点では既に 支点間の付着は損失し，ipb シリーズ試験体と同様，定 着性能のみで作用せん断力に抵抗したためである.

同図に示すように，最大せん断応力は定着性能が低下 するに従い減少する傾向を示した．また，a/d が小さい ほど同一定着性能に対する最大せん断応力は大きい.こ のことは，本実験のように定着領域まで荷重伝達がなさ れる場合では，せん断而讨力は定着性能と a/d が大きく影 響することが認められる.

そこで，アンボンド試験体の定着性能を完全アーチ状 態時の定着性能と仮定し，その定着性能で基準化した定 着不良試験体の定着性能と $a / d$ を説明変数とし，アーチ

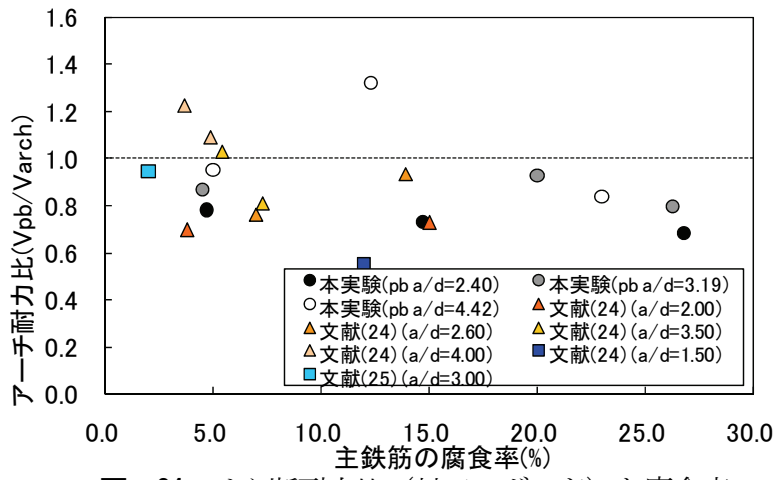

図一34 せん断耐力比（対アンボンド）と腐食率

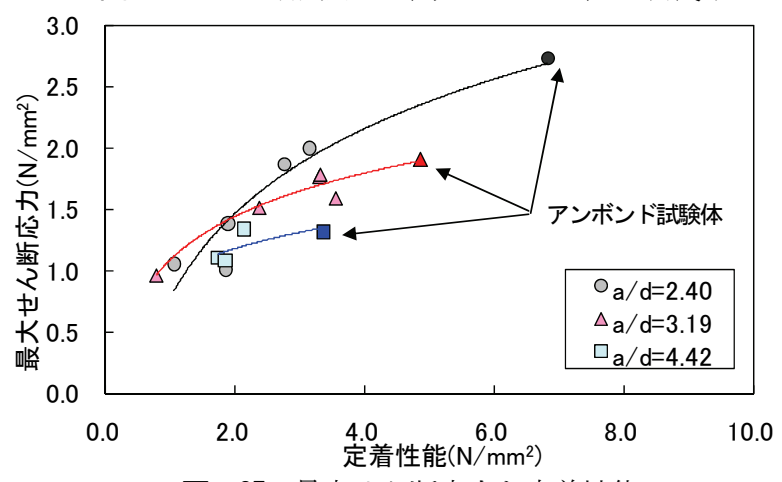

図一35 最大せん断応力と定着性能

耐力比を目的変数として重回帰分析を行った結果, 式 (4)に示す回帰式が得られた.

$$
\frac{V_{\text {cor }}}{V_{\text {arch }}}=1-\left(0.941\left(1-\frac{\tau_{\text {cor }}}{\tau_{\text {arch }}}\right)-0.0748(\mathrm{a} / \mathrm{d})\right) \leq 1.0
$$

ここで， $V_{\text {cor }}$ : 定着不良試験体のせん断耐力, $V_{\text {arch }}$ : ア ンボンド試験体のせん断耐力, $\tau_{\text {cor }}$ : 定着不良試験体の 定着性能， $\tau_{\text {arch }}$ : アンボンド試験体の定着性能である. 式(4)から得られるアーチ耐力比と実験值の比較を図 -36 に示す. 自由度調整済夕決定係数は 0.88 であり, 本実験の範囲内では，定着性能と a/d を用いてア一チ耐 力比を良好に評価することが可能であることが示された。

\section{（4）せん断耐力評価モデル}

前節では，アンボンド試験体を基準として定着性能お よび a/d を変数としたせん断耐力評価式(4)を提案した. そこで，本節では断面諸元ならびに載荷条件の異なる試 験体に対して，提案した評価式の適用性について検討す る. 適用性評価に用いた試験体は，L-SO, L-SA, H-SO,

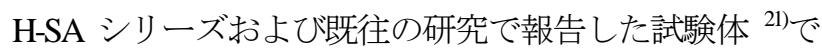
ある.

式(4)の適用に際し，完全ア一チ時の定着性能 $\left(\tau_{\text {arch }}\right)$ が必 要となるため, 以下に示すように算出した.

図－37 はアンボンド試験体の終局時の鉄筋力とせん 断耐力の比 $\left(T_{\text {arch }} / V_{\text {arch }}\right)$ と a/d の関係を示したものであ る. ここで，実験における鉄筋力は，最大荷重時の試験 体端部から 400mm 1550mm の鉄筋ひずみの平均值に鉄 


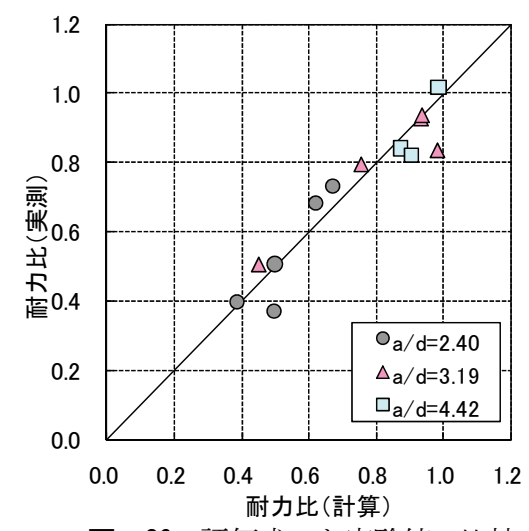

図-36 評価式(4)と実験值の比較

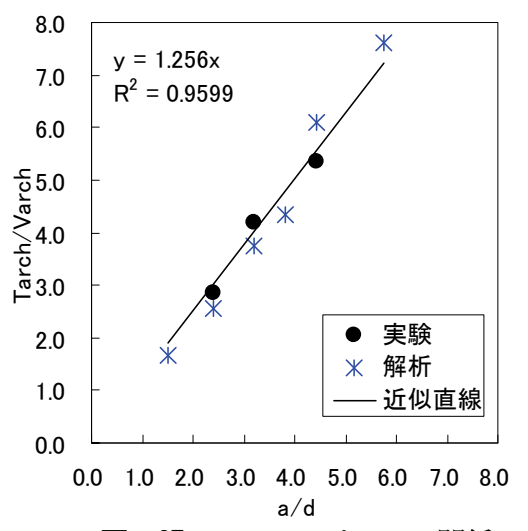

図一37 $T_{\text {arch }} / V_{\text {arch }}$ と $a / d$ 関係

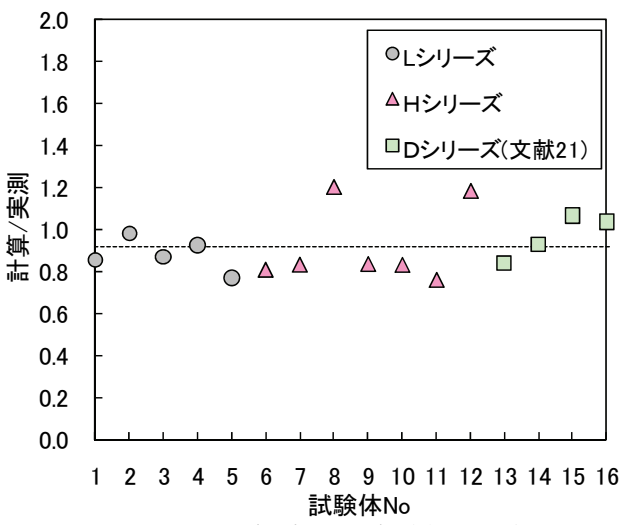

図-38 評価式(7) と実験值の比較
筋の断面積および弾性係数を乗じて算出した。

図一37 に示寸ように，鉄筋力とせん断力の比は a/d に 比べて若干大きな值を示し， a/d の増加にしたがい線形 的に増加する傾向が認められる。

図－37 の関係を線形近似すれば，アンボンド試験体 の終局時の鉄筋力は次式に示寸ようになる.

$$
T_{\text {arch }}=1.256(a / d) \cdot V_{\text {arch }}
$$

ここで, $T_{\text {arch }}$ : アンボンド試験体の終局時の鉄筋力で ある.

アンボンド試験体では支点間の付着が無いことから， 鉄筋力は定着性能によって保持される. 完全ア一チ状態 の定着性能 $\left(\tau_{\text {arch }}\right)$ は，鉄筋径，定着領域，鉄筋量の本 数を用いて次式より算出した.

$$
\tau_{\text {arch }}=\frac{T_{\text {arch }}}{n \cdot l_{d} \cdot \pi \cdot D}
$$

ここで, $n$ : 主鉄筋の本数, $D$ : 鉄筋径, $l_{d}$ : 定着領域, $T_{\text {arch }}:$ 終局時の鉄筋力である.

なお，定着領域 $l_{d}$ にいては，前述したひずみ分布性 状から，支点外側の領域+100mm とした.

最終的に定着不良試験体のせん断耐力は, 式(3)〜(6) より，式(7)に示すようになる.

$$
\begin{aligned}
& \frac{V_{\text {cor }}}{V_{\text {arch }}}=1-\left(0.941\left(1-\frac{\tau_{\text {cor }}}{\tau_{\text {arch }}}\right)-0.0748(a / d)\right) \leq 1.0 \\
& \tau_{\text {arch }}=\frac{1.256(a / d) V_{\text {arch }}}{n \cdot l_{d} \cdot \pi \cdot D} \\
& V_{\text {arch }}=[4.861 \exp (-0.402 \cdot a / d)] V_{c}
\end{aligned}
$$

図ー38 は実測の耐力と算定結果の比を試験体毎に示 したものである. 算定值の平均は 0.92, 変動係数は 0.14 であり，算定値は実測值と比較的良好な一致を示した。

本研究において，前述のひずみ分布性状より，支点よ りさらに内側に $100 \mathrm{~mm}$ までを定着領域（l $l_{d}$ ) として評価 式を提案した．図一38 に示すように，定着長が異なる
試験体においても算定值と実験值は比較的良好な一致を 示しており，上記定着長の設定は妥当であると考えられ る.また，定着性能は鉄筋ひずみデータを用いて算定し たが，実構造物においてそのようなデータを取得するこ とは困難である。しかしながら，既往の研究において， 鉄筋の腐食性状や腐食ひび割れ性状などの腐食劣化因子 に基づく付着性能を評価する試みがなされている ${ }^{26}$. 今 後, 腐食劣化因子に基づいて定着性能を定量的に評価可 能とすることにより，外観変状から定着不良を生じた $\mathrm{RC}$ 部材の現有の構造性能を評価寸ることが出来ると考 えられるが，これは今後の課題としたい.

\section{6. 主鉄筋の定着性能に基づく腐食はりの耐荷機 構の判定}

鉄筋腐食を生じた RC はり部材は，設計時に想定した 破壊モードから遷移寸る場合があることを示した．そこ で本章では，非腐食時に曲げ破壊が先行する鉄筋腐食 RC はり部材の残存而荷機構を整理することとする．鉄 筋腐食を生じた RC はり部材の残存而荷機構の流れは図 -39のように表すことができる.

鉄筋腐食を生じた RC はり部材の破壊モードは，主鉄 筋の軸方向における腐食の不均一性（分岐 1）により異 なり，偏差率を導入して整理した．主鉄筋の腐食性状が 均一な状態（偏差率 0.9 以下）では，せん断補強筋の有 無により分岐が生じる（分岐 2）。せん断補強筋を有す る場合, せん断補強筋の腐食率（分岐 3）が小さいと, せん断区間の付着劣化が抑制され，定着領域まで荷重が 伝達されないことにより曲げ破壊を生じる。この際の曲 げ而和は，主鉄筋の材料劣化を加味した曲げ理論により 評価可能である（経路(1)）。一方，せん断補強筋の腐 食率が大きいと，その拘束効果がなくなり，せん断補強 筋を有しない場合と同様の破壊性状を示すこととなる. 寸なわち，せん断補強筋を有しない或いは過度に腐食が 生じた場合，定着領域まで荷重が伝達され，はりの耐荷 


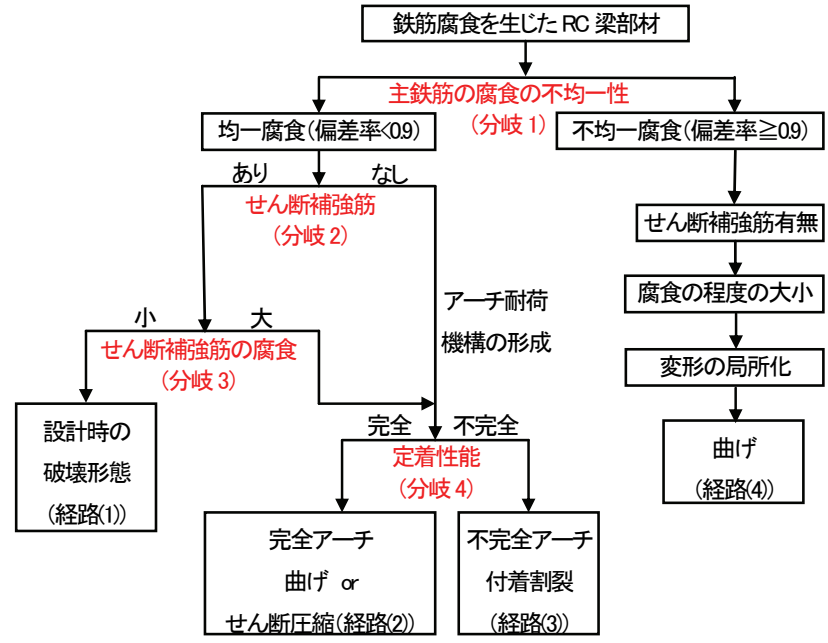

図一39 鉄筇腐食を生じた RCはり部材の耐荷機構の流れ

機構はアーチ機構に移行することとなる.この際，定着 性能（分岐 4）によって破壊形態が異なり，定着が完全 な状態では完全なア一チ耐荷機構が形成されることに対 して，定着が不完全な状態では不完全なアーチとなる. 前者においては，鉄筋が降伏しなければ曲げ圧縮破壊， 或いはせん断圧縮破壊となり，鉄筋降伏が生じれば曲げ 引張破壊となる（経路(2)）。後者では，定着劣化の程 度に応じた付着割裂破壊を生じる（経路(3)）。この際 の耐力は式(7)により評価される，腐食したせん断補強 筋の拘束効果は，主鉄筋下側のせん断補強筋の残存量が 拘束効果に影響を及ぼすことは既往の研究で明らかとな っているが，その定量化については今後の課題である ${ }^{14)}$. 主鉄筋の腐食性状が不均一な状態（偏差率 0.9 以上） では，腐食が過度に生じた箇所において変形が局所化し， 曲げ破壊を生じる（経路(4)）。仮に偏差率が 0.9 以上と なる箇所が多く存在すると，等曲げ区間或いはその近傍 において偏差率が最も大きい箇所で破壊が支配されると 考えられる.このような場合には腐食率の平均值のみで はなく最も腐食が進んだ領域における腐食率により耐力 比の整理が必要となる. なお，主鉄筋の不均一な腐食に より曲げ而对がせん断耐力に比べて大きくなるような試 験体は，本研究の範囲内では存在しないが，そのような ケースは考えにくく，曲げ耐力がせん断耐力に比べて小 さくなる状態のみを対象としてもよいであろう.

経路(3)の耐力は，式(7)に示した関係から評価可能で あるが，現有の定着性能が入力值として必要となる.今 後, 定着性能と鉄筋腐食率および腐食ひび割れ性状など の劣化指標との関連付け行い，これら劣化指標から定着 性能を評価する手法の構築が課題である.

\section{7. 結論}

本研究では形状・寸法の異なる RC はり部材に対して
鉄筋腐食によって定着不良を生じた場合の残存耐荷性状 について実験的検討を行うとともに，その評価手法を提 案した。 以下に本研究で得られた知見を示す.

(1) 曲げ破壊が先行型の RC はり部材において，せん断 補強筋が比較的残存する場合，主鉄筋の付着損失が 抑制され，はりは，曲け破壊を示す。その場合，主 鉄筋の材料劣化が而荷力に支配的な影響を及ぼし, 試験体の形状・寸法によらず主鉄筋の材料劣化を考 慮した曲げ理論により耐力を評価可能である.

(2) 曲げ破壊先行型の RC はり部材において，主鉄筋の 腐食の不均一性が生じた場合，部材の局所的な材料 劣化に耐力は支配される.

（3）鉄筋腐食性状に応じた RC はり部材における而荷機 構の設計時からの分岐経路が定性的に明らかとなっ た.

（4）せん断補強筋が過度に腐食或いは消失した場合にお いては，定着領域まで荷重伝達がなされた場合，ア 一千而荷機構が形成される.この場合におけるはり の破壊形態および耐力は，定着性能および a/d に依 存する.

（5）ア一千而荷機構が形成される場合の破壊形態は，定 着不良が生じた場合，不完全なア一チ機構となり破 壊形態は付着割裂破壊となる。一方，定着が完全な 状態では，完全なア一チ機構が形成され，はりの破 壊形態は曲げ破壊或いはせん断圧縮破壊を生じるこ ととなり，せん断耐荷力の低下は大幅に抑制される。

(6) 定着不良によって不完全なア一チ機構が形成された 場合のせん断耐力は，せん断スパン比と定着性能に 基づき，ある程度評価することができる

\section{参考文献}

1) 土木学会 : 材料劣化が生じたコンクリート構造物の 構造性能,コンクリート技術シリーズ 71, 2006.

2) 大屋戸理明, 金久保利之, 山本泰彦, 佐藤勉 : 鉄筋 の腐食性状が鉄筋コンクリート部材の曲げ性状に与 える影響, 土木学会論文集, Vol.62, No.3, pp.542554, 2006.

3）青山敏幸, 下村匠, 丸山久一：塩害により鉄筋が腐 食した RC 部材の曲げ性状，コンクリート工学年次論 文集，Vol.20，No.2，pp.883-888，1998.

4) 岩波光保, 横田弘, 佐藤文則 : 鉄筋腐食が RC はりの 耐荷性能に及ぼす影響, コンクリート工学年次論文 集, Vol.24, No.2, pp.1501-1506, 2002.

5) 花岡大伸, 矢野真義, 宮里心一：鉄筋コンクリート 梁の腐食形態と腐食量が曲げ性状に及ぼす影響, 土 木学会論文集，Vol.63，No.2，pp.300-312， 2007.

6) 村上祐貴, 山内佑樹, 堤知明, 大下英吉 : 鉄筋腐食 した RC 部材の残存曲げ而力に及ぼすせん断補強筋の 影響評価，コンクリート工学年次論文集，Vol.28, No.2, pp.727-732, 2006.

7）村上祐貴，木下哲秀，鈴木修一，福本幸成，大下英 吉 : 鉄筋腐食を生じた RC 梁部材の残存曲げ耐力性状 
に関する研究，コンクリート工学論文集，Vol.17, No.1, pp.61-74, 2006.1.

8) 佐藤吉孝, 山本貴士，服部篤史，宮川豊章：せん断 補強筋および主筋の腐食が RC 部材のせん断耐荷特性 に与える影響, コンクリート工学年次論文集, Vol.25, No.1, pp.821-826, 2003.

9) 佐藤吉孝, 山本貴士，服部篤史，宮川豊章 : 鉄筋腐 食の生じた RC 部材のせん断耐荷特性の検討, アップ グレード論文報告集，Vol.4，pp.33-38， 2004.

10）松尾豊史，酒井理哉，松村卓郎，金津努：鉄筋腐食 した RCはり部材のせん断耐荷機構に関する研究，コ ンクリート工学論文集, Vol.15, No.2, pp.69-77, 2004.

11）橋本航，森川英典，小林秀恵：鉄筋腐食を考慮した RC はり部材のせん断耐荷性能評価, コンクリート工 学年次論文集, Vol.25, No.2, pp.1009-1014, 2003.

12) 角田真彦, 渡辺健, 三木朋広, 二羽淳一郎：局所的 な鉄筋腐食を有する RC はり部材のせん断耐荷性能に 関する研究，コンクリート工学年次論文集，Vol.30, No.3, pp.175-1710, 2008.

13）宮川豊章：アルカリ骨材反応による鉄筋破断が生じ た構造物の安全性評価, 土木学会誌, Vol.88, No.9, pp.83-84, 2003.9.

14）村上祐貴，大下英吉，鈴木修一，堤知明：鉄筋腐食 した RC 梁部材の残存耐力性状に及ぼすせん断補強筋 ならびに定着性能の影響に関する研究, 土木学会論 文集 E，Vol.64，No.4，pp.631-649，2008.12.

15）河村圭亮, Tran Khoa Kim, 中村光, 国枝実 : 鉄筋腐 食に伴うコンクリートの表面および内部ひび割れ進 展挙動，コンクリート工学年次論文集，Vol.32，No.1， pp.1007-1012, 2010.

16) 前川宏一, 中村光, 佐藤靖彦, Kukrit Toongoenthong : せん断補強筋の定着不良が RC はり のせん断耐力に及ぼす影響, コンクリート工学年次 論文集，Vol.26, No.2, pp.973-978, 2004.

17）村上祐貴, 董衛, 鈴木修一, 大下英吉 : 鉄筋腐食の
不均一性が RC 梁部材の残存曲げ而荷性能に及ぼす影 響, コンクリート工学年次論文集, Vol.31, No.2, pp.709-714, 2009.

18) Hordijk, D. A. : Local Approach to Fatigue of Concrete, Doctor dissertation, Delft University of Technology, 1991.

19) Kolmar, W. : Beschreibung der Kraftuebertragung uber Risse in nichtlinearen Finite-Element-Berechnungen von Stahlbetontragwerken, Dissertation, T. H. Darmstadt, p. 94, 1986.

20) 二羽淳一郎, 山田一宇, 横沢和夫, 岡村甫 : せん断 補強鉄筋を用いない RC はりのせん断強度式の再評価, 土木学会論文集，第 325 号/V-5, pp.167-176, 1986.

21）村上祐貴，塩谷文涁，堤知明，大下英吉：鉄筋腐食 した RCはり部材の残存耐荷性能に及ぼす定着性能の 影響, コンクリート工学年次論文集, Vol.32, No.2, pp.1489-1494, 2010.

22) 渡辺充弘, 村山八洲雄, 西村伸一: 著しい付着劣化 を想定したアンボンド RC 部材のせん断耐荷性状，農 業土木学会大会講演会講演要旨集, pp.574-575, 2005.

23) 村山八洲雄, 津野将太郎, 井八口諭, 鎌田光 : 露出 鉄筋を有する鉄筋コンクリート部材の曲げ耐力に関 する実験的研究, コンクリート工学年次論文集, Vol.31, No.2, pp.697-702, 2009.

24) 広森紳太郎, Xin Xue, 関博 : 軸引張鉄筋が腐食した せん断スパン比の異なる RCはり部材のせん断耐力に ついて, コンクリート工学年次論文集, Vol.31, No.2, pp.1537-1542, 2009.

25) 大家戸理明 : 腐食した鉄筋コンクリート部材の力学 性能の評価, 博士論文, 2007 .

26) 董衛, 大下英吉, 鈴木修一, 堤知明： Predicted Method for Bond Stress Behavior Depended on Crack Width in Corroded Reinforced Concrete, コンクリート 工学年次論文集, Vol.33, No.2, pp.631-636, 2011.

\title{
STUDY ON CHARACTERISTICS OF RESIDUAL STRENGTH OF RC BEAMS WITH DEFECTIVE ANCHORAGES DUE TO CORROSION OF REINFORCEMENTS
}

\author{
Yuki MURAKAMI, Wei DONG, Hideki OSHITA, Shuichi SUZUKI \\ and Tomoaki TSUTSUMI
}

In this study, to evaluate flexural strength and shear strength with defective anchorages due to corrosion of reinforcement, the bending test of the RC beams received damage in the anchorage region due to corrosion was carried out. As a result, it is seems that the residual shear strength of RC beams with defective anchorages depends on shear span ratio in addition to the anchorage performance. Furthermore, the authors propose an evaluation model for an shear strength of RC beams with defective anchorages on the basis of these experimental results and analytical result. The value of residual shear strength calculated using this model corresponds to the test results in the past. 